\title{
A Series of Supramolecular Complexes for Solar Energy Conversion via Water Reduction to Produce Hydrogen: An Excited State Kinetic Analysis of Ru(II),Rh(III),Ru(II) Photoinitiated Electron Collectors
}

\author{
Travis A. White, Jessica D. Knoll, Shamindri M. Arachchige and Karen J. Brewer * \\ Department of Chemistry, Virginia Tech, Blacksburg, VA 24061-0212, USA; \\ E-Mails: whiteta@vt.edu (T.A.W.); jdknoll@vt.edu (J.D.K.); arachsm@vt.edu (S.M.A.) \\ * Author to whom correspondence should be addressed; E-Mail: kbrewer@vt.edu; \\ Tel.: +1-540-231-6579; Fax: +1-540-231-3255.
}

Received: 3 November 2011; in revised form: 12 December 2011 / Accepted: 19 December 2011 / Published: 27 December 2011

\begin{abstract}
Mixed-metal supramolecular complexes have been designed that photochemically absorb solar light, undergo photoinitiated electron collection and reduce water to produce hydrogen fuel using low energy visible light. This manuscript describes these systems with an analysis of the photophysics of a series of six supramolecular complexes, $\left[\left\{(\mathrm{TL})_{2} \mathrm{Ru}(\mathrm{dpp})\right\}_{2} \mathrm{RhX}_{2}\right]\left(\mathrm{PF}_{6}\right)_{5}$ with $\mathrm{TL}=$ bpy, phen or $\mathrm{Ph}_{2}$ phen with $\mathrm{X}=\mathrm{Cl}$ or $\mathrm{Br}$. The process of light conversion to a fuel requires a system to perform a number of complicated steps including the absorption of light, the generation of charge separation on a molecular level, the reduction by one and then two electrons and the interaction with the water substrate to produce hydrogen. The manuscript explores the rate of intramolecular electron transfer, rate of quenching of the supramolecules by the DMA electron donor, rate of reduction of the complex by DMA from the ${ }^{3}$ MLCT excited state, as well as overall rate of reduction of the complex via visible light excitation. Probing a series of complexes in detail exploring the variation of rates of important reactions as a function of sub-unit modification provides insight into the role of each process in the overall efficiency of water reduction to produce hydrogen. The kinetic analysis shows that the complexes display different rates of excited state reactions that vary with TL and halide. The role of the MLCT excited state is elucidated by this kinetic study which shows that the ${ }^{3}$ MLCT state and not the ${ }^{3} \mathrm{MMCT}$ is likely that key contributor to the photoreduction of these complexes. The kinetic analysis of the excited state dynamics and reactions of the complexes are
\end{abstract}


important as this class of supramolecules behaves as photoinitiated electron collectors and photocatalysts for the reduction of water to hydrogen.

Keywords: intramolecular electron transfer; photoinitiated electron collection; supramolecular photocatalysis; excited state quenching; hydrogen production

\section{Introduction}

The demand for alternative fuel sources is continually increasing. An attractive approach to this issue is the conversion of solar energy to chemical energy in the form of $\mathrm{H}_{2} \mathrm{O}$ splitting to produce $\mathrm{H}_{2}$ fuel $[1,2]$. At neutral $\mathrm{pH}$ and $25^{\circ} \mathrm{C}, \mathrm{H}_{2} \mathrm{O}$ can be split into $\mathrm{H}_{2}$ and $\mathrm{O}_{2}$ via a multi-electron pathway that requires $1.23 \mathrm{~V}$ [3]. Sunlight provides an abundant amount of energy to the Earth's surface that contains the required energy to drive this thermodynamically uphill, multi-electron reaction. However, $\mathrm{H}_{2} \mathrm{O}$ does not absorb an appreciable amount of sunlight reaching the surface, therefore systems must be designed to efficiently absorb light and deliver appropriate charges to $\mathrm{H}_{2} \mathrm{O}$. One means of achieving this goal is through the use of supramolecular complexes [4]. In this arena, supramolecular complexes are described as molecular machines comprised of multiple molecular components whose individual properties contribute to the overall functioning of the system [5]. Supramolecular complexes of interest in solar energy conversion schemes are photochemical molecular devices (PMDs) as they perform a specific light-driven task utilizing solar energy as the thermodynamic driving force for a desired chemical reaction. Engineering PMDs to perform specific, complex functions at the molecular level allows for the exploitation of these systems as potential photocatalysts. Systems can be designed to perform photoinduced vectoral electron transfer and charge migration between appropriate electron donor (ED), such as an electron rich, metal-based light absorber (LA), and electron acceptor (EA) sites. Generating this photoinduced charge separation and migration within PMDs is of considerable interest in the realm of solar energy conversion schemes [5].

An application of PMDs is the generation of multielectron photocatalysts that utilize photoinduced processes to deliver multiple reducing equivalents to a central site which may interact with an appropriate substrate. Photoinitiated electron collectors (PECs) are a type of PMD typically comprised of metal-based LA subunits covalently bound to an electron collecting (EC) site through polyazine bridging ligands (BL) $[4,6]$. Varying the molecular components within the PEC such as polypyridyl terminal ligands (TL) and polyazine BLs attached to the LA modulates the photoactive and redox-active properties of the PECs. The first reported PMD for PEC, $\left[\left\{(\mathrm{bpy})_{2} \mathrm{Ru}(\mathrm{dpb})\right\}_{2} \mathrm{IrCl}_{2}\right]\left(\mathrm{PF}_{6}\right)_{5}$ (bpy = 2,2'-bipyridine; $\mathrm{dpb}=2,3$-bis(2-pyridyl)benzoquinoxaline) undergoes electron collection on the dpb BL $\pi^{*}$ LUMO upon visible light excitation [6]. The homobimetallic complexes [(phen $\left.)_{2} \mathrm{Ru}(\mathrm{BL}) \mathrm{Ru}(\mathrm{phen})_{2}\right]\left(\mathrm{PF}_{6}\right)_{4}$ collect up to two or four electrons on the BL $\left(\pi^{*}\right)$ orbitals (phen $=1,10$-phenanthroline; $\mathrm{BL}=9,11,20$, 22-tetraazatetrapyrido[3,2-a:2'3'-c:3", $2^{\prime \prime}-1: 2^{\prime \prime \prime}, 3^{\prime \prime \prime}$-n] pentacene (tatpp) or 9,11,20,22-tetraazatetrapyrido [3,2-a:2'3'-c:3", 2"-1:2'", $3^{\prime \prime \prime}-$-n]pentacene-10,21-quinone (tatpq)) [7,8]. The Ru monometallic [(bpy) $)_{2} \mathrm{Ru}$ $(\mathrm{pbn})]\left(\mathrm{PF}_{6}\right)_{2}$ undergoes proton-coupled two-electron reduction of the NAD/NADH ${ }^{+}$model ligand to produce $\left[(\text { bpy })_{2} \mathrm{Ru}(\mathrm{pbnHH})\right]^{2+}(\mathrm{pbn}=2$-(2-pyridyl $)$ benzo $[b]-1,5$-naphthyridine, $\mathrm{NAD}=$ nicotinamide 
adenine dinucleotide) $[9,10]$. These early systems display ligand-centered photoinitiated electron collection, but do not perform photocatalytic reduction of $\mathrm{H}_{2} \mathrm{O}$ to $\mathrm{H}_{2}$.

Modifying the $\left[\left\{(\mathrm{bpy})_{2} \mathrm{Ru}(\mathrm{dpb})\right\}_{2} \mathrm{IrCl}_{2}\right]\left(\mathrm{PF}_{6}\right)_{5}$ trimetallic by changing the $\mathrm{BL}$ from dpb to dpp and the central metal from $\operatorname{Ir}(\mathrm{III})$ to $\mathrm{Rh}(\mathrm{III})$ generates $\left[\left\{(\text { bpy })_{2} \mathrm{Ru}(\mathrm{dpp})\right\}_{2} \mathrm{RhCl}_{2}\right]\left(\mathrm{PF}_{6}\right)_{5}$ (dpp $=2,3$-bis (2-pyridyl)pyrazine) [11]. This $\mathrm{Ru}(\mathrm{II}), \mathrm{Rh}(\mathrm{III}), \mathrm{Ru}(\mathrm{II})$ trimetallic complex displays orbital inversion with the LUMO now localized on the Rh(III) metal center and is the first reported PEC to collect multiple reducing equivalents at a central metal site while staying intact. Intramolecular electron transfer from the $\mathrm{Ru}(\mathrm{II})$-based LAs to the $\mathrm{Rh}$ (III)-based EC subunit produces a doubly-reduced $\mathrm{Rh}$ metal center with the potential to deliver electrons to a substrate. Further modification of the $\left[\left\{(\mathrm{TL})_{2} \mathrm{Ru}(\mathrm{dpp})\right\}_{2} \mathrm{RhX}_{2}\right]^{5+}$ molecular components through halide variation, as well as TL variation, has generated a series of complexes functioning as PECs. In the presence of a sacrificial ED and $\mathrm{H}_{2} \mathrm{O}$, many of the $\mathrm{Rh}$ centered PECs function as photocatalysts reducing $\mathrm{H}_{2} \mathrm{O}$ to $\mathrm{H}_{2}$ [12-16]. Figure 1 displays an example of an ED-LA-BL-EC-BL-LA-ED structural motif for PEC and the required orbital energetics. Photoexcitation at $470 \mathrm{~nm}$ produces $7.2 \pm 0.7 \mu \mathrm{mol}$ of $\mathrm{H}_{2}$ in an $\mathrm{CH}_{3} \mathrm{CN}$ solvent system with

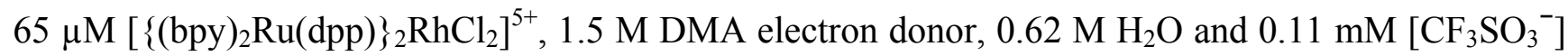
$\left[\mathrm{DMAH}^{+}\right]$after $5 \mathrm{~h}(\mathrm{DMA}=N, N$-dimethylaniline). Halide variation to the weaker $\sigma$-donating $\mathrm{Br}$ finely tunes the orbital energetics at the Rh site, while TL variation to phen or $\mathrm{Ph}_{2}$ phen tunes the light absorbing capabilities of these systems with both expected to affect photocatalysis $\left(\mathrm{Ph}_{2}\right.$ phen $=4,7$-diphenyl-1, 10-phenanthroline). Systematic component variation within this series of $\mathrm{Ru}(\mathrm{II}), \mathrm{Rh}(\mathrm{III}), \mathrm{Ru}(\mathrm{II})$ trimetallics allows for careful analysis of the excited state properties that influence photocatalysis of $\mathrm{H}_{2} \mathrm{O}$ to $\mathrm{H}_{2}$.

Figure 1. Photoinitiated electron collection at a central site using the ED-LA-BL-EC-BLLA-ED structural motif ( $\mathrm{ED}=$ sacrificial electron donor; $\mathrm{LA}=$ light absorber; $\mathrm{BL}=$ bridging ligand; $\mathrm{EC}=$ electron collector; et $=$ intramolecular electron transfer). Structure for the $\mathrm{Ru}(\mathrm{II}), \mathrm{Rh}(\mathrm{III}), \mathrm{Ru}(\mathrm{II})$ supramolecular complex $\left[\left\{(\text { phen })_{2} \mathrm{Ru}(\mathrm{dpp})\right\}_{2} \mathrm{RhBr}_{2}\right]\left(\mathrm{PF}_{6}\right)_{5}$ is also shown (phen $=1,10$-phenanthroline; dpp = 2,3-bis(2-pyridyl)pyrazine).
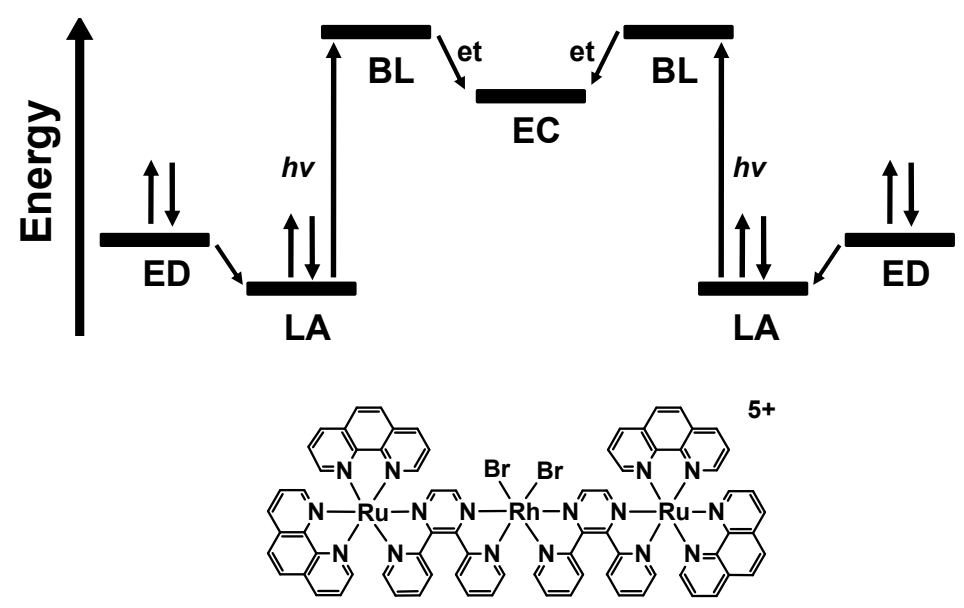

Intermolecular electron transfer reactions have been widely studied focusing on the development of molecular photovoltaics [17-20]. Ru(II)-based polyazine LAs are efficient light absorbers throughout the UV and visible regions as photoexcitation populates ${ }^{3} \mathrm{MLCT}$ (metal-to-ligand charge transfer) 
excited states with near unit efficiency that are photo- and redox-active. The prototypical light absorber $\left[\mathrm{Ru}(\mathrm{bpy})_{3}\right]^{2+}$ undergoes optical excitation to populate an emissive ${ }^{3} \mathrm{MLCT}$ electronic excited state that is both a more powerful oxidizing and reducing agent than the ground state species. Upon photoexcitation, this class of $\mathrm{Ru}(\mathrm{II})$-polyazine LAs are known to undergo excited state oxidative and reductive quenching, Equations (1-3).

$$
\begin{gathered}
{\left[\mathrm{Ru}(\mathrm{bpy})_{3}\right]^{2+} \stackrel{h v}{\longrightarrow} *\left[\mathrm{Ru}(\mathrm{bpy})_{3}\right]^{2+}} \\
*\left[\mathrm{Ru}^{\mathrm{II}}(\mathrm{bpy})_{3}\right]^{2+}+\mathrm{EA} \rightarrow\left[\mathrm{Ru}^{\mathrm{III}}(\mathrm{bpy})_{3}\right]^{3+}+\mathrm{EA}^{-} \\
*\left[\mathrm{Ru}^{\mathrm{II}}(\mathrm{bpy})_{3}\right]^{2+}+\mathrm{ED} \rightarrow\left[\mathrm{Ru}^{\mathrm{II}}(\mathrm{bpy})_{2}\left(\mathrm{bpy}^{-}\right)\right]^{+}+\mathrm{ED}^{+}
\end{gathered}
$$

The rate of excited state electron transfer depends on the thermodynamic driving force for these reactions $[4,21,22]$. The excited state oxidation (Equation 4) and reduction (Equation 5) potentials of the excited LA are calculated using the energy of the $\mathrm{E}^{0-0}$ transition of the ${ }^{3}$ MLCT emission and the ground state redox potentials.

$$
\begin{aligned}
& E\left({ }^{*} \mathrm{LA}^{+} / \mathrm{LA}\right) \approx E\left(\mathrm{LA} / \mathrm{LA}^{+}\right)-\mathrm{E}^{0-0} \\
& E\left({ }^{*} \mathrm{LA} / \mathrm{LA}^{-}\right) \approx E\left(\mathrm{LA} / \mathrm{LA}^{-}\right)+\mathrm{E}^{0-0}
\end{aligned}
$$

In the equations above, $\mathrm{LA}$ is the $\mathrm{Ru}(\mathrm{II})$-polyazine light absorber, $E\left(\mathrm{LA} / \mathrm{LA}^{+}\right)$is the ground state oxidation potential, $E\left(\mathrm{LA} / \mathrm{LA}^{-}\right)$is the ground state reduction potential, $E\left({ }^{*} \mathrm{LA}^{+} / \mathrm{LA}\right)$ is the excited state oxidation potential, and $E\left({ }^{*} \mathrm{LA} / \mathrm{LA}^{-}\right)$is the excited state reduction potential. Emission spectroscopy is often used to probe the rate of quenching of the emissive ${ }^{3}$ MLCT excited states by a quenching species, such as an ED [23,24]. Supramolecular complexes take advantage of covalently coupled molecular components to promote photoinduced intramolecular electron transfer. Bridging a $\mathrm{Ru}$ (II)-based LA to an EA subunit (LA-EA) can afford excited state intramolecular electron transfer upon photoexcitation of the LA subunit, as shown in Equations 6 and 7.

$$
\begin{aligned}
& \text { LA-EA } \stackrel{h v}{\longrightarrow} \text { *LA-EA } \\
& * \text { LA-EA } \rightarrow \text { LA }^{+}-\mathrm{EA}^{-}
\end{aligned}
$$

Several $\mathrm{Ru}(\mathrm{II}), \mathrm{Rh}(\mathrm{III})$ bimetallic [25-31] and $\mathrm{Ru}(\mathrm{II}), \mathrm{Rh}(\mathrm{III}), \mathrm{Ru}(\mathrm{II})$ trimetallic [11-13,16,32] systems have been reported that undergo photoinduced intramolecular electron transfer. The $\mathrm{Ru}(\mathrm{II}), \mathrm{Rh}(\mathrm{III}) \quad$ bimetallic complexes $\quad\left[(\mathrm{bpy})_{2} \mathrm{Ru}\left(\mathrm{Mebpy}-\mathrm{CH}_{2} \mathrm{CH}(\mathrm{OH}) \mathrm{CH}_{2}-\mathrm{Mebpy}\right) \mathrm{Rh}(\mathrm{bpy})_{2}\right]^{5+}$ and $\left[\left(\mathrm{Me}_{2} \text { phen }\right)_{2} \mathrm{Ru}\left(\mathrm{Mebpy}-\mathrm{CH}_{2} \mathrm{CH}_{2}-\mathrm{Mebpy}\right) \mathrm{Rh}\left(\mathrm{Me}_{2} \text { bpy }\right)_{2}\right]^{5+}$ (Mebpy = 4-methyl-2,2'-bipyridine; $\mathrm{Me}_{2}$ phen = 4,7-dimethyl-1,10-phenanthroline; $\mathrm{Me}_{2}$ bpy = 4,4'-dimethyl-2,2'-bipyridine) covalently couple the Ru-based LA and Rh-based EA through aliphatic BLs, affording rates of intramolecular electron transfer $\left(\mathrm{k}_{\mathrm{et}}\right)$ of $1.4 \times 10^{7}$ and $1.7 \times 10^{8} \mathrm{~s}^{-1}$, respectively [25,29]. Electronic communication between the two metal centers was negligible due to the nature of the BL and the distance between the metal centers. Modification of the BL to incorporate aromatic linkers displayed a strong dependence on the calculated $\mathrm{k}_{\mathrm{et}}$ value to the distance between metal centers. With each additional phenylene linker in the $\mathrm{Ru}(\mathrm{II}), \mathrm{Rh}(\mathrm{III})$ complexes [(Me 2 phen $)_{2} \mathrm{Ru}$-bpy-(ph) $)_{\mathrm{n}}$-bpy- $\left.\mathrm{Rh}\left(\mathrm{Me}_{2} \mathrm{bpy}\right)_{2}\right]^{5+}$ (where $\mathrm{n}=1,2$, or 3), values for $\mathrm{k}_{\mathrm{et}}$ decrease by an order of magnitude with $\mathrm{k}_{\mathrm{et}}=3.0 \times 10^{9} \mathrm{~s}^{-1}, 4.3 \times 10^{8} \mathrm{~s}^{-1}$ and $1.0 \times 10^{7} \mathrm{~s}^{-1}$, respectively [26]. Similar to the aliphatic bridged $\mathrm{Ru}(\mathrm{II}), \mathrm{Rh}(\mathrm{III})$ bimetallics, the phenylene linker-containing complexes display negligible electronic communication between the metal centers. 
Further modification of the aromatic BL scaffold to include pyrazine components strongly influences $\mathrm{k}_{\mathrm{et}}$. The complexes $\left[(\mathrm{bpy})_{2} \mathrm{Ru}(\mathrm{dpp}) \mathrm{Rh}(\mathrm{bpy})_{2}\right]^{5+},\left[(\mathrm{tpy}) \mathrm{Ru}(\mathrm{tpp}) \mathrm{RhCl}_{3}\right]^{2+}$, and $\left[(\mathrm{bpy})_{2} \mathrm{Ru}(\mathrm{dpp}) \mathrm{RhCl}_{2}\right.$ (phen) $]^{3+}$ (tpy $=2,2^{\prime}: 6^{\prime}, 2^{\prime \prime}$-terpyridine; tpp $=$ 2,3,5,6-tetrakis(2-pyridyl)pyrazine) have values of $\mathrm{k}_{\mathrm{et}}=2.8,4.0$, and $2.5 \times 10^{7} \mathrm{~s}^{-1}$, respectively [30,31,33]. Substantial electronic communication between the metal centers greatly perturbs the observed photophysical properties of these coupled $\mathrm{Ru}(\mathrm{II}), \mathrm{Rh}(\mathrm{III})$ bimetallics.

Reported herein is a study of the excited state dynamics and a kinetic analysis of the quenching of the ${ }^{3}$ MLCT excited states by the electron donor DMA as well as the kinetics of formation of a reduced $\mathrm{Rh}$ species within the supramolecular architecture $\left[\left\{(\mathrm{TL})_{2} \mathrm{Ru}(\mathrm{dpp})\right\}_{2} \mathrm{RhX}_{2}\right]\left(\mathrm{PF}_{6}\right)_{5}(\mathrm{TL}=$ bpy, phen or $\mathrm{Ph}_{2}$ phen; $\mathrm{X}=\mathrm{Cl}$ or $\mathrm{Br}$ ), Figure 2. These supramolecules are known to function as photoinitiated electron collectors and photocatalysts in the reduction of $\mathrm{H}_{2} \mathrm{O}$ to $\mathrm{H}_{2}$. This structural motif provides for systems that are strong oxidizers in their excited state which allows use of electron donors and oxidation chemistry not accessible to typical $\left[\mathrm{Ru}(\mathrm{bpy})_{3}\right]^{2+}$ based systems. The role of component modification on excited state dynamics and reaction rates is analyzed.

Figure 2. $\mathrm{Ru}(\mathrm{II}), \mathrm{Rh}(\mathrm{III}), \mathrm{Ru}(\mathrm{II})$ photoinitiated electron collectors of the supramolecular architecture $\left[\left\{(\mathrm{TL})_{2} \mathrm{Ru}(\mathrm{dpp})\right\}_{2} \mathrm{RhX}_{2}\right]^{5+}\left(\mathrm{TL}=\right.$ bpy $=2,2^{\prime}$-bipyridine, phen $=1,10$-phenanthroline, $\mathrm{Ph}_{2}$ phen = 4,7-diphenyl-1,10-phenanthroline; $\mathrm{dpp}=2,3$-bis (2-pyridyl)pyrazine; $\mathrm{X}=\mathrm{Cl}$ or $\mathrm{Br}$ ).

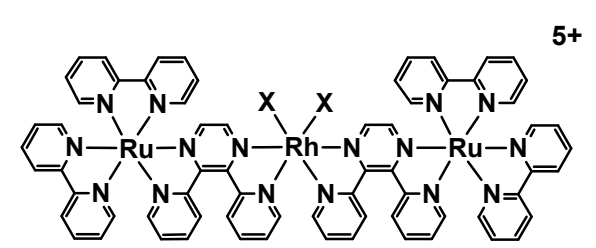

$\left[\left\{(b p y){ }_{2} \operatorname{Ru}(d p p)\right\}_{2} \operatorname{RhX}_{2}\right]^{5+}$

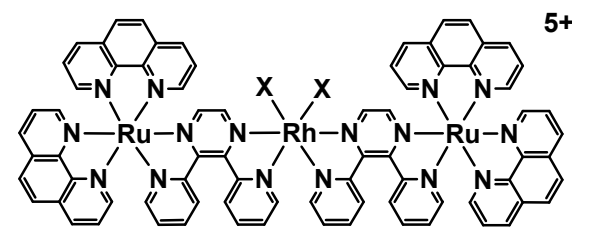

$\left[\left\{(\text { phen })_{2} \operatorname{Ru}(\mathrm{dpp})\right\}_{2} \operatorname{RhX}_{2}\right]^{5+}$

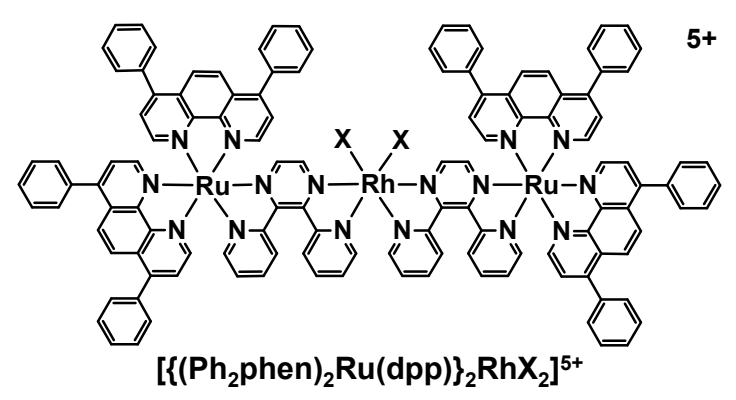

\section{Results and Discussion}

\subsection{Photophysical Properties}

The $\left[\left\{(\mathrm{TL})_{2} \mathrm{Ru}(\mathrm{dpp})\right\}_{2} \mathrm{RhX}_{2}\right]^{5+}$ trimetallic complexes are efficient light absorbers throughout the UV and visible regions at room temperature in acetonitrile, Figure 3. The UV region is dominated by intense $\mathrm{TL} \pi \rightarrow \pi^{*}$ intraligand (IL) transitions, with the dpp BL $\pi \rightarrow \pi^{*}$ IL transitions occurring at slightly lower energy. The visible region displays higher energy $\operatorname{Ru}(\mathrm{d} \pi) \rightarrow \mathrm{TL}\left(\pi^{*}\right) \mathrm{CT}$ transitions and lowest energy $\operatorname{Ru}(\mathrm{d} \pi) \rightarrow \operatorname{dpp}\left(\pi^{*}\right)$ CT transitions. The lowest-lying MLCT transition is nearly isoenergetic in the series of complexes indicative of the similar $\operatorname{Ru}(\mathrm{d} \pi) \rightarrow \mathrm{dpp}\left(\pi^{*}\right)$ CT nature of the optically populated state. 
These systems absorb more of the solar spectrum than typical $\left[\mathrm{Ru}(\mathrm{bpy})_{3}\right]^{2+}$ based systems via enhanced molar absorptivity in the UV and visible with $\operatorname{Ru}(\mathrm{d} \pi) \rightarrow \mathrm{dpp}\left(\pi^{*}\right) \mathrm{CT}$ transitions that provide absorption in the low energy visible.

Figure 3. Electronic absorption spectra for the complexes (A) $\left[\left\{(\mathrm{TL})_{2} \mathrm{Ru}(\mathrm{dpp})\right\}_{2} \mathrm{RhCl}_{2}\right]^{5+}$, where $\mathrm{TL}=$ bpy $(-)$, phen $(--), \mathrm{Ph}_{2}$ phen $(\cdots)$ and $(\mathbf{B})\left[\left\{(\mathrm{TL})_{2} \mathrm{Ru}(\mathrm{dpp})\right\}_{2} \mathrm{RhBr}_{2}\right]^{5+}$, where TL $=$ bpy $(-)$, phen $(---), \mathrm{Ph}_{2}$ phen $(\cdots)$.
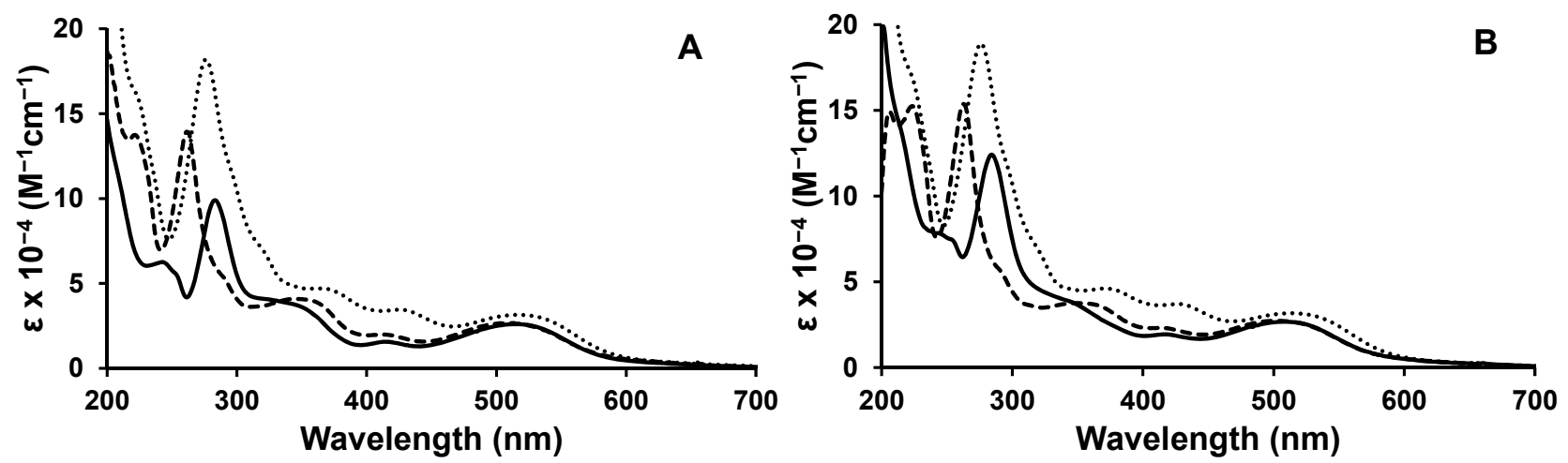

The excited state properties of the $\mathrm{Ru}(\mathrm{II}), \mathrm{Rh}(\mathrm{III}), \mathrm{Ru}(\mathrm{II})$ trimetallic and model $\mathrm{Ru}(\mathrm{II}), \mathrm{Ru}(\mathrm{II})$ bimetallic complexes are summarized in Table 1 . The trimetallic complexes of the design $\left[\left\{(\mathrm{TL})_{2} \operatorname{Ru}(\mathrm{dpp})\right\}_{2}\right.$ $\left.\mathrm{RhX}_{2}\right]^{5+}\left(\mathrm{TL}=\right.$ bpy, phen, $\mathrm{Ph}_{2}$ phen; $\mathrm{X}=\mathrm{Cl}$ or $\mathrm{Br}$ ) display weak emission and a short excited state lifetime of the $\operatorname{Ru}(\mathrm{d} \pi) \rightarrow \operatorname{dpp}\left(\pi^{*}\right){ }^{3} \mathrm{MLCT}$ emissive excited state when compared with the model $\left[(\mathrm{TL})_{2} \mathrm{Ru}(\mathrm{dpp}) \mathrm{Ru}(\mathrm{TL})_{2}\right]^{4+}$ bimetallic complexes, which display the same $\mathrm{Ru} \rightarrow \mu$-dpp ${ }^{3} \mathrm{MLCT}$ emissive state but lack a Rh-based EC metal center. The $\mathrm{Ru}(\mathrm{II}), \mathrm{Ru}(\mathrm{II})$ bimetallic complexes are used as model systems for photophysical studies due to the similar nature and energy of the emissive $\mathrm{Ru} \rightarrow \mu$-dpp CT excited state. Terminal ligand variation has been shown to modulate this ${ }^{3}$ MLCT emissive excited state (presumably from a contribution to the formally $\mathrm{Ru}(\mathrm{d} \pi) \mathrm{HOMO}$ in this motif), therefore different $\mathrm{Ru}(\mathrm{II}), \mathrm{Ru}(\mathrm{II})$ bimetallics are needed for $\mathrm{TL}=$ bpy, phen, or $\mathrm{Ph}_{2}$ phen [32]. Figure 4 displays the state diagram for the trimetallic complex $\left[\left\{\left(\mathrm{Ph}_{2} \text { phen }\right)_{2} \mathrm{Ru}(\mathrm{dpp})\right\}_{2} \mathrm{RhBr}_{2}\right]\left(\mathrm{PF}_{6}\right)_{5}$. At $\mathrm{RT}$, deactivation from the ${ }^{3}$ MLCT excited state is dominated by intramolecular electron transfer to populate a low-lying, energetically close $\mathrm{Ru}(\mathrm{d} \pi) \rightarrow \mathrm{Rh}\left(\mathrm{d} \sigma^{*}\right){ }^{3} \mathrm{MMCT}$ excited state. This is supported by the observation of a Rh-based lowest unoccupied molecular orbital (LUMO) in electrochemical analyses of these systems [11-13,15,16]. The shortened excited state lifetime of the emissive ${ }^{3}$ MLCT state in the Ru(II), $\mathrm{Rh}(\mathrm{III}), \mathrm{Ru}(\mathrm{II})$ motif at RT is ascribed to intramolecular electron transfer to populate a low-lying ${ }^{3}$ MMCT state which quenches the ${ }^{3}$ MLCT state at RT but not at $77 \mathrm{~K}$ [32]. Due to the similar energy and nature of the emissive ${ }^{3} \mathrm{MLCT}$ excited state for the $\mathrm{Ru}(\mathrm{II}), \mathrm{Ru}(\mathrm{II})$ bimetallic and $\mathrm{Ru}(\mathrm{II}), \mathrm{Rh}(\mathrm{III})$, $\mathrm{Ru}$ (II) trimetallic complexes, it is assumed that calculated rate constants for radiative $\left(\mathrm{k}_{\mathrm{r}}\right)$ and non-radiative $\left(\mathrm{k}_{\mathrm{nr}}\right)$ decay from the ${ }^{3} \mathrm{MLCT}$ excited state of the bimetallics are the same for the analogous trimetallics. Both the title trimetallics and the model bimetallic used as the model for each trimetallic possess not only the same $\mathrm{Ru}(\mathrm{d} \pi) \rightarrow \mathrm{dpp}\left(\pi^{*}\right){ }^{3} \mathrm{MLCT}$ emissive state but also the same TL and the same $(\mathrm{TL})_{2} \mathrm{Ru}^{\mathrm{II}}(\propto-\mathrm{dpp})$ sub-unit. Under this assumption, the rate constant for intramolecular electron transfer $\left(\mathrm{k}_{\mathrm{et}}\right)$ to populate the non-emissive ${ }^{3} \mathrm{MMCT}$ excited state was calculated and varies from (1.4-2.8) $\times 10^{7} \mathrm{~s}^{-1}$ in this series of complexes. Within each series of $\mathrm{TL}=$ bpy, phen, $\mathrm{or}^{\mathrm{Ph}}{ }_{2} \mathrm{phen}$ 
trimetallics, varying the halide from $\mathrm{Cl}$ to $\mathrm{Br}$ displays a decrease in $\Phi^{\mathrm{em}}$ and $\tau$ with a subsequent increase in $\mathrm{k}_{\mathrm{et}}$. The inclusion of the weaker $\sigma$-donating $\mathrm{Br}$ stabilizes the ${ }^{3} \mathrm{MMCT}$ excited state and affords enhanced driving force and rate of intramolecular electron transfer to populate the ${ }^{3} \mathrm{MMCT}$ state. Choice of $\mathrm{TL}$ within the $\mathrm{Ru}(\mathrm{II}), \mathrm{Rh}(\mathrm{III}), \mathrm{Ru}(\mathrm{II})$ architecture also impacts the excited state properties with the energy, $\Phi^{\mathrm{em}}$, and $\tau$ of the formally $\operatorname{Ru}(\mathrm{d} \pi) \rightarrow \operatorname{dpp}\left(\pi^{*}\right){ }^{3} \mathrm{MLCT}$ excited state varying. The phen systems display enhanced rates of intramolecular electron transfer to populate the ${ }^{3} \mathrm{MMCT}$ state vs. bpy or $\mathrm{Ph}_{2}$ phen. The phen systems have slightly higher energy ${ }^{3} \mathrm{MLCT}$ excited states which may provide a larger driving force for electron transfer to populate the ${ }^{3} \mathrm{MMCT}$ state.

Table 1. Photophysical Properties of $\left[\left\{(\mathrm{TL})_{2} \mathrm{Ru}(\mathrm{dpp})\right\}_{2} \mathrm{RhX}_{2}\right]^{5+}$ Trimetallic and Analogous $\left[(\mathrm{TL})_{2} \mathrm{Ru}(\mathrm{dpp}) \mathrm{Ru}(\mathrm{TL})_{2}\right]^{4+}$ Bimetallic Complexes at Room Temperature and $77 \mathrm{~K}$.

\begin{tabular}{|c|c|c|c|c|c|c|c|c|}
\hline \multirow[b]{2}{*}{ Complex } & \multicolumn{6}{|c|}{$\mathrm{RT}^{a}$} & \multicolumn{2}{|c|}{$77 \mathrm{~K}^{b}$} \\
\hline & $\begin{array}{c}\lambda_{\max }^{\mathrm{em}} \\
(\mathbf{n m})\end{array}$ & $\begin{array}{c}\Phi_{\mathrm{MLCT}}^{\mathrm{em}} \\
\left(\mathbf{1 0}^{-3}\right)^{c}\end{array}$ & $\begin{array}{c}\tau \\
(\mathrm{ns})^{d}\end{array}$ & $\begin{array}{c}k_{\mathrm{r}} \\
\left(10^{3} \mathrm{~s}^{-1}\right)\end{array}$ & $\begin{array}{c}k_{\mathrm{nr}} \\
\left(10^{6} \mathrm{~s}^{-1}\right)\end{array}$ & $\begin{array}{c}\mathbf{k}_{\mathrm{et}} \\
\left(10^{7} \mathbf{s}^{-1}\right)\end{array}$ & $\begin{array}{c}\lambda_{\max }^{e m} \\
(\mathrm{~nm})\end{array}$ & $\begin{array}{c}\tau \\
(\mu \mathrm{s})^{d}\end{array}$ \\
\hline$\left[(\mathrm{bpy})_{2} \mathrm{Ru}(\mathrm{dpp}) \mathrm{Ru}(\mathrm{bpy})_{2}\right]^{4+}$ & 752 & 0.97 & 145 & 6.7 & 6.9 & & 730 & 2.4 \\
\hline$\left[(\text { phen })_{2} \operatorname{Ru}(\mathrm{dpp}) \operatorname{Ru}(\text { phen })_{2}\right]^{4+}$ & 750 & 1.6 & 170 & 9.4 & 5.9 & & 695 & 2.0 \\
\hline$\left[\left(\mathrm{Ph}_{2} \text { phen }\right)_{2} \mathrm{Ru}(\mathrm{dpp}) \mathrm{Ru}\left(\mathrm{Ph}_{2} \text { phen }\right)_{2}\right]^{4+}$ & 754 & 1.7 & 192 & 9.0 & 5.2 & & 698 & 2.0 \\
\hline$\left[\left\{(\mathrm{bpy})_{2} \mathrm{Ru}(\mathrm{dpp})\right\}_{2} \mathrm{RhCl}_{2}\right]^{5+}$ & 776 & 0.26 & 38 & 6.7 & 6.9 & 1.9 & 716 & 1.9 \\
\hline$\left[\left\{(\mathrm{bpy})_{2} \mathrm{Ru}(\mathrm{dpp})\right\}_{2} \mathrm{RhBr}_{2}\right]^{5+}$ & 776 & 0.14 & 34 & 6.7 & 6.9 & 2.3 & 716 & 1.9 \\
\hline$\left[\left\{(\text { phen }){ }_{2} \mathrm{Ru}(\mathrm{dpp})\right\}_{2} \mathrm{RhCl}_{2}\right]^{5+}$ & 760 & 0.22 & 35 & 9.4 & 5.9 & 2.3 & 706 & 1.8 \\
\hline$\left[\left\{(\mathrm{phen}){ }_{2} \mathrm{Ru}(\mathrm{dpp})\right\}_{2} \mathrm{RhBr}_{2}\right]^{5+}$ & 760 & 0.17 & 30 & 9.4 & 5.9 & 2.8 & 706 & 1.9 \\
\hline$\left[\left\{\left(\mathrm{Ph}_{2} \mathrm{phen}\right)_{2} \mathrm{Ru}(\mathrm{dpp})\right\}_{2} \mathrm{RhCl}_{2}\right]^{5+}$ & 770 & 0.24 & 52 & 9.0 & 5.2 & 1.4 & 696 & 1.8 \\
\hline$\left[\left\{\left(\mathrm{Ph}_{2} \text { phen }\right)_{2} \mathrm{Ru}(\mathrm{dpp})\right\}_{2} \mathrm{RhBr}_{2}\right]^{5+}$ & 770 & 0.20 & 40 & 9.0 & 5.2 & 2.0 & 696 & 1.9 \\
\hline
\end{tabular}

${ }^{a}$ Measured in acetonitrile at room temperature; ${ }^{b}$ Measured in $4: 1 \mathrm{EtOH} / \mathrm{MeOH}$ rigid matrix at $77 \mathrm{~K} ;{ }^{c}$ Reported values of $\Phi \pm 5 \%$; ${ }^{d}$ Reported values of $\tau \pm 5 \%$.

Figure 4. State diagram for $\left[\left\{(\mathrm{TL})_{2} \mathrm{Ru}(\mathrm{dpp})\right\}_{2} \mathrm{RhX}_{2}\right]\left(\mathrm{PF}_{6}\right)_{5}$ trimetallic complexes, illustrated for $\left[\left\{\left(\mathrm{Ph}_{2} \text { phen }\right)_{2} \mathrm{Ru}(\mathrm{dpp})\right\}_{2} \mathrm{RhBr}_{2}\right]\left(\mathrm{PF}_{6}\right)_{5}\left(\mathrm{TL}=\right.$ bpy, phen or $\mathrm{Ph}_{2}$ phen; $\mathrm{X}=\mathrm{Cl}$ or $\left.\mathrm{Br}\right) . h v$ is energy of the photon, $k_{i s c}$ is the rate constant for intersystem crossing, $k_{r}$ is the rate constant for radiative decay, $k_{n r}$ is the rate constant for non-radiative decay, $k_{e t}$ is the rate constant for intramolecular electron transfer, and $k_{r x n}$ is the rate constant for a photochemical reaction.

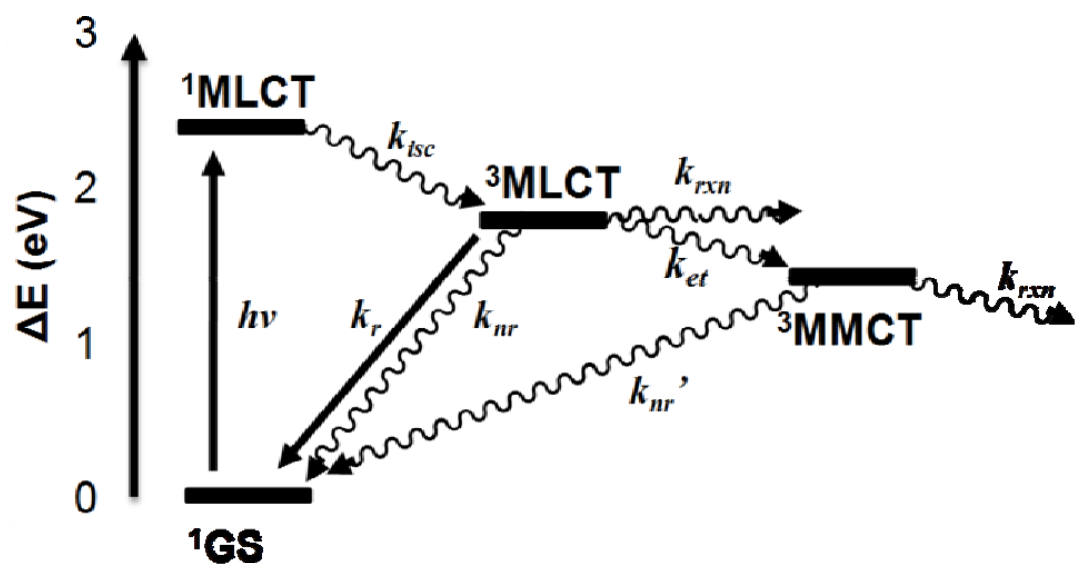


At $77 \mathrm{~K}$ in a rigid glass matrix, the $\mathrm{Ru}(\mathrm{II}), \mathrm{Rh}(\mathrm{III}), \mathrm{Ru}(\mathrm{II})$ trimetallic and $\mathrm{Ru}(\mathrm{II}), \mathrm{Ru}(\mathrm{II})$ bimetallic complexes display similar emissive excited states with nearly equivalent lifetimes. The shape of the ${ }^{3}$ MLCT emission profile sharpens in rigid media at $77 \mathrm{~K}$ and the emission maxima blue shift. This is consistent with electron transfer at RT to populate the ${ }^{3} \mathrm{MMCT}$ state from the emissive ${ }^{3} \mathrm{MLCT}$ state being impeded at $77 \mathrm{~K}$ in a rigid media.

\subsection{Photochemical Properties}

Photochemical reduction of these $\left[\left\{(\mathrm{TL})_{2} \mathrm{Ru}(\mathrm{dpp})\right\}_{2} \mathrm{Rh}^{\mathrm{III}} \mathrm{X}_{2}\right]^{5+}$ trimetallic complexes illustrates their ability to undergo photoinitiated electron collection at the $\mathrm{Rh}(\mathrm{III})$ metal center to generate $\mathrm{Rh}(\mathrm{I})$ centered trimetallics. When illuminated at $470 \mathrm{~nm}$ in the presence of the sacrificial electron donor DMA, the electronic absorption spectrum displays a shift to higher energy of the $\operatorname{Ru}(\mathrm{d} \pi) \rightarrow \operatorname{dpp}\left(\pi^{*}\right) \mathrm{CT}$ transition due to the formation of a more electron-rich $\mathrm{Rh}(\mathrm{I})$ metal center. The increase in electron density at $\mathrm{Rh}$ destabilizes the $\mathrm{dpp}\left(\pi^{*}\right)$ acceptor orbitals relative to $\mathrm{Rh}(\mathrm{III})$ resulting in an increase in the energy of the observed $\operatorname{Ru}(\mathrm{d} \pi) \rightarrow \operatorname{dpp}\left(\pi^{*}\right)$ CT transition. The electronic absorption spectra generated through electrochemical reduction of the $\mathrm{Rh}(\mathrm{III})$ to $\mathrm{Rh}(\mathrm{I})$ metal center correlates well with the photochemical reduction of trimetallics [11]. The reduction of these complexes occurs via an ECEC mechanism analogous to previously studied $\left[\mathrm{Rh}(\mathrm{NN})_{2} \mathrm{X}_{2}\right]^{+}$, Figure $5[34,35]$.

Figure 5. Mechanism for the electrochemical reduction of $\left[\left\{(\mathrm{TL})_{2} \mathrm{Ru}(\mathrm{dpp})\right\}_{2} \mathrm{RhX} \mathrm{X}_{2}\right]^{5+}$ ( $\mathrm{TL}=$ bpy, phen or $\mathrm{Ph}_{2}$ phen; $\mathrm{X}=\mathrm{Cl}$ or $\mathrm{Br}$ ).

\begin{tabular}{|c|c|}
\hline Synthesized state & 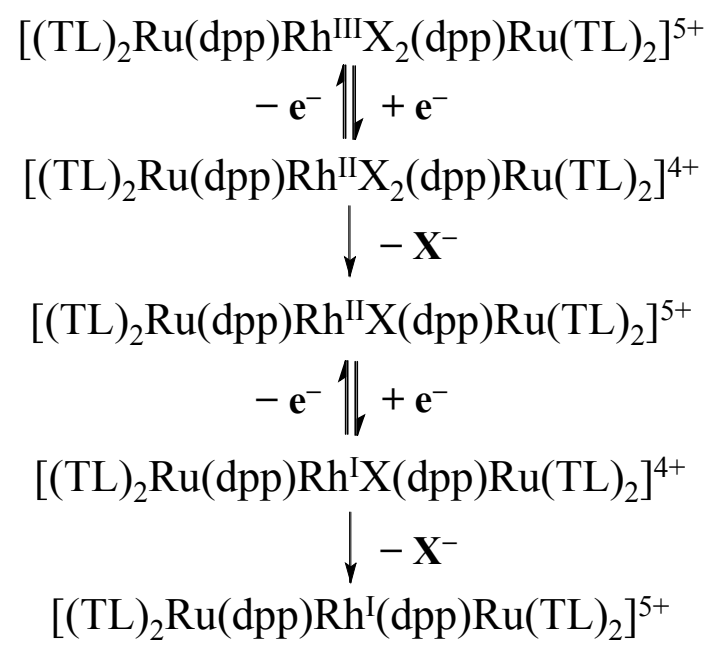 \\
\hline
\end{tabular}

The photochemical reduction of the complexes $\left[\left\{(\mathrm{TL})_{2} \mathrm{Ru}(\mathrm{dpp})\right\}_{2} \mathrm{Rh}^{\mathrm{III}} \mathrm{X}_{2}\right]^{5+}$ is critical to photocatalysis and involves many steps including possible reactions from the ${ }^{3} \mathrm{MLCT}$ and ${ }^{3} \mathrm{MMCT}$ excited states. Generation of the two electron reduced species $\left[\left\{(\mathrm{TL})_{2} \mathrm{Ru}(\mathrm{dpp})\right\}_{2} \mathrm{Rh}^{\mathrm{I}}\right]^{5+}$ forms through a $\mathrm{Rh}(\mathrm{II})$ intermediate as observed electrochemically with $\left[\mathrm{Rh}(\mathrm{bpy})_{2} \mathrm{Cl}_{2}\right]^{+}$and $\left[\mathrm{Rh}(\mathrm{dpp})_{2} \mathrm{Br}_{2}\right]^{+}[34,35]$. Photochemically, this reduced species can be formed through intermolecular electron transfer from a sacrificial electron donor to the ${ }^{3} \mathrm{MLCT}$ or ${ }^{3} \mathrm{MMCT}$ excited states. Additionally, both excited states can undergo unimolecular or bimolecular deactivation. The present kinetic study will analyze the rate of intramolecular electron transfer described above, the rate of quenching of the ${ }^{3}$ MLCT state via Stern-Volmer analysis and the rate of photochemical reduction via spectroscopic analysis. These 
pathways are all critical to formation of the $\mathrm{Ru}(\mathrm{II}), \mathrm{Rh}(\mathrm{II}), \mathrm{Ru}(\mathrm{II})$ form of the complexes. Equations 8-15 display the various kinetic pathways for the formation of the singly-reduced $\mathrm{Ru}(\mathrm{II}), \mathrm{Rh}(\mathrm{II}), \mathrm{Ru}(\mathrm{II})$ photoreduced product. The $\left[\left\{(\mathrm{TL})_{2} \mathrm{Ru}(\mathrm{dpp})\right\}_{2} \mathrm{RhX}_{2}\right]^{5+}$ trimetallic complexes are represented as $\mathrm{Ru}^{\mathrm{II}}(\mathrm{dpp}) \mathrm{Rh}^{\mathrm{III}}(\mathrm{dpp}) \mathrm{Ru}^{\mathrm{II}}$.

\section{MLCT Excitation:}

$$
\mathrm{Ru}^{\mathrm{II}}(\mathrm{dpp}) \mathrm{Rh}^{\mathrm{III}}(\mathrm{dpp}) \mathrm{Ru}^{\mathrm{II}} \stackrel{h v}{\rightarrow} * \mathrm{Ru}^{\mathrm{III}}\left(\mathrm{dpp}^{-}\right) \mathrm{Rh}^{\mathrm{III}}(\mathrm{dpp}) \mathrm{Ru}{ }^{\mathrm{II}}
$$

Unimolecular Deactivation of ${ }^{3}$ MLCT State:

$$
\text { * } \mathrm{Ru}^{\mathrm{III}}\left(\mathrm{dpp}^{-}\right) \mathrm{Rh}^{\mathrm{III}}(\mathrm{dpp}) \mathrm{Ru}^{\mathrm{II}} \stackrel{k_{1}}{\rightarrow} \mathrm{Ru} \mathrm{u}^{\mathrm{II}}(\mathrm{dpp}) \mathrm{Rh}^{\mathrm{III}}(\mathrm{dpp}) \mathrm{Ru}^{\mathrm{II}}
$$

$\underline{\text { Bimolecular Deactivation of }{ }^{3} \text { MLCT State: }}$

$$
\mathrm{DMA}+* \mathrm{Ru}^{\mathrm{III}}\left(\mathrm{dpp}^{-}\right) \mathrm{Rh}^{\mathrm{III}}(\mathrm{dpp}) \mathrm{Ru}^{\mathrm{II}} \stackrel{k_{2}}{\rightarrow} \mathrm{Ru}^{\mathrm{II}}(\mathrm{dpp}) \mathrm{Rh}^{\mathrm{III}}(\mathrm{dpp}) \mathrm{Ru}^{\mathrm{II}}+\mathrm{DMA}
$$

Reductive Quenching of ${ }^{3}$ MLCT State:

$$
\mathrm{DMA}+* \mathrm{Ru}^{\mathrm{III}}\left(\mathrm{dpp}^{-}\right) \mathrm{Rh}^{\mathrm{III}}(\mathrm{dpp}) \mathrm{Ru}^{\mathrm{II}} \stackrel{k_{q}}{\rightarrow} \mathrm{Ru}^{\mathrm{II}}(\mathrm{dpp}) \mathrm{Rh}^{\mathrm{II}}(\mathrm{dpp}) \mathrm{Ru}^{\mathrm{II}}+\mathrm{DMA}^{+}
$$

$\underline{\text { Intramolecular Electron Transfer: }}$

$$
* \mathrm{Ru}^{\mathrm{III}}\left(\mathrm{dpp}^{-}\right) \mathrm{Rh}^{\mathrm{III}}(\mathrm{dpp}) \mathrm{Ru}^{\mathrm{II}} \stackrel{k_{e t}}{\rightarrow} * \mathrm{Ru}^{\mathrm{III}}(\mathrm{dpp}) \mathrm{Rh}^{\mathrm{II}}(\mathrm{dpp}) \mathrm{Ru}^{\mathrm{II}}
$$

Unimolecular Deactivation of ${ }^{3}$ MMCT State:

$$
* \mathrm{Ru}^{\mathrm{III}}\left(\mathrm{dpp}^{-}\right) \mathrm{Rh}^{\mathrm{III}}(\mathrm{dpp}) \mathrm{Ru}^{\mathrm{II}} \stackrel{k_{4}}{\rightarrow} * \mathrm{Ru}^{\mathrm{III}}(\mathrm{dpp}) \mathrm{Rh}^{\mathrm{II}}(\mathrm{dpp}) \mathrm{Ru}^{\mathrm{II}}
$$

Bimolecular Deactivation of ${ }^{3}$ MMCT State:

$$
\mathrm{DMA}+* \mathrm{Ru}^{\mathrm{III}}(\mathrm{dpp}) \mathrm{Rh}^{\mathrm{II}}(\mathrm{dpp}) \mathrm{Ru} \stackrel{\mathrm{II}^{\mathrm{k}}}{\stackrel{k_{3}}{\rightarrow}} \mathrm{Ru}^{\mathrm{II}}(\mathrm{dpp}) \mathrm{Rh}^{\mathrm{III}}(\mathrm{dpp}) \mathrm{Ru} \mathrm{II}^{\mathrm{II}}+\mathrm{DMA}
$$

$\underline{\text { Reductive Quenching of }{ }^{3} \text { MLCT State: }}$

$$
\mathrm{DMA}+* \mathrm{Ru}^{\mathrm{III}}(\mathrm{dpp}) \mathrm{Rh}^{\mathrm{II}}(\mathrm{dpp}) \mathrm{Ru}^{\mathrm{II}} \stackrel{k_{q 2}}{\rightarrow} \mathrm{Ru}^{\mathrm{II}}(\mathrm{dpp}) \mathrm{Rh}^{\mathrm{II}}(\mathrm{dpp}) \mathrm{Ru}^{\mathrm{II}}+\mathrm{DMA}^{+}
$$

Using our mechanism, unimolecular deactivations $\mathrm{k}_{1}$ and $\mathrm{k}_{4}$ include radiative, $\mathrm{k}_{\mathrm{r}}$, and non-radiative, $\mathrm{k}_{\mathrm{nr}}$, decay including relaxation mediated by solvent. Bimolecular deactivations, $\mathrm{k}_{2}$ and $\mathrm{k}_{3}$, include electron transfer from DMA followed by rapid back electron transfer as well as other bimolecular deactivations by DMA.

\subsection{Emission Quenching}

The emissive nature of the ${ }^{3}$ MLCT excited state provides a handle to study the excited state dynamics. This probe was used to study the rate of intramolecular electron transfer $\left(\mathrm{k}_{\mathrm{et}}\right)$ as described above. Addition of the ED DMA provides a means to assay the kinetics of quenching of the ${ }^{3}$ MLCT state by this ED. The sacrificial electron donor DMA has been shown to quench the ${ }^{3}$ MLCT emissive excited state of Ru-polyazine complexes and $\left[\left\{(\text { bpy })_{2} \mathrm{Ru}(\mathrm{dpp})\right\}_{2} \mathrm{RhCl}_{2}\right]^{5+}$ through bimolecular interactions [11]. The $\left[\left\{(\mathrm{TL})_{2} \mathrm{Ru}(\mathrm{dpp})\right\}_{2} \mathrm{RhX}_{2}\right]^{5+}$ trimetallic complexes reported herein undergo efficient excited state reductive quenching of the ${ }^{3}$ MLCT emission. DMA is reported to quench the ${ }^{3}$ MLCT emission of $\left[\mathrm{Ru}(\mathrm{bpy})_{3}\right]^{2+}[23,36]$ and $\left[\mathrm{Ru}(\mathrm{bpz})_{3}\right]^{2+}\left(\mathrm{bpz}=2,2^{\prime}\right.$-bipyrazine $)$ [37] with a rate constant of 
$7.1 \times 10^{7} \mathrm{M}^{-1} \mathrm{~s}^{-1}$ and $8.4 \times 10^{9} \mathrm{M}^{-1} \mathrm{~s}^{-1}$, respectively. The ${ }^{3} \mathrm{MLCT}$ excited state of $*\left[\mathrm{Ru}(\mathrm{bpy})_{3}\right]^{2+}$ and $*\left[\mathrm{Ru}(\mathrm{bpz})_{3}\right]^{2+}$ have excited state reduction potentials of $0.82 \mathrm{~V}$ and $1.50 \mathrm{~V}$ vs. $\mathrm{Ag} / \mathrm{AgCl}$, respectively, while DMA has a ground state oxidation potential of $0.86 \mathrm{~V} v s . \mathrm{Ag} / \mathrm{AgCl}$ [36]. The thermodynamic driving force $\left(E_{\text {redox }}\right)$ for reductive quenching of the ${ }^{3}$ MLCT excited state is determined by the ground state oxidation potential of the electron donor $\left(E\left(E^{0 /+}\right)\right)$ and the excited state reduction potential of the $\mathrm{Ru}(\mathrm{II})$-polyazine complex $\left(E\left({ }^{*} \mathrm{CAT}^{\mathrm{n}+} / \mathrm{CAT}^{(\mathrm{n}-1) \dagger}\right)\right)$, Equations 16 and 17:

$$
\begin{gathered}
\mathrm{E}_{\text {redox }}=\mathrm{E}\left({ }^{*} \mathrm{CAT}^{\mathrm{n}+} / \mathrm{CAT}^{(\mathrm{n}-1)+}\right)-\mathrm{E}\left(\mathrm{ED}^{0 /+}\right) \\
\left.\mathrm{E}^{*} \mathrm{CAT}^{\mathrm{n}+} / \mathrm{CAT}^{(\mathrm{n}-1)+}\right)=\mathrm{E}^{0-0}+\mathrm{E}\left(\mathrm{CAT}^{\mathrm{n}+} / \mathrm{CAT}^{(\mathrm{n}-1)+}\right)
\end{gathered}
$$

where $E\left(\mathrm{CAT}^{\mathrm{n}+} / \mathrm{CAT}^{(\mathrm{n}-1)^{+}}\right)$is the ground state reduction potential of the complex and $\mathrm{E}^{0-0}$ is the energy of the 0-0 transition between the excited state and the ground state. The $\mathrm{E}^{0-0}$ energy is estimated using the observed $77 \mathrm{~K}$ emission maxima. Using the above calculations, $E_{\text {redox }}$ for the excited state reductive quenching of $*\left[\mathrm{Ru}(\mathrm{bpy})_{3}\right]^{2+}$ by DMA is a thermodynamically unfavorable process $\left(E_{\text {redox }}=-0.04 \mathrm{~V}\right)$ and supports the observed low rate, $7.1 \times 10^{7} \mathrm{M}^{-1} \mathrm{~s}^{-1}$. Conversely, $*\left[\mathrm{Ru}(\mathrm{bpz})_{3}\right]^{2+}$ has a thermodynamically favorable value of $E_{\text {redox }}(+0.64 \mathrm{~V})$ for excited state reductive quenching using DMA with a larger rate, $8.4 \times 10^{9} \mathrm{M}^{-1} \mathrm{~s}^{-1}$, close to the diffusion control limit [38]. The thermodynamic driving force strongly impacts the excited state reductive quenching of these $\mathrm{Ru}(\mathrm{II})$-polyazine complexes [23,37,39]. $\left[\left\{(\mathrm{TL})_{2} \mathrm{Ru}(\mathrm{dpp})\right\}_{2} \mathrm{RhX}_{2}\right]^{5+}$ trimetallic complexes display positive values of $E_{\text {redox }}$ for the reductive quenching of the ${ }^{3} \mathrm{MLCT}$, as well as ${ }^{3} \mathrm{MMCT}$, excited states with the ${ }^{3} \mathrm{MLCT}$ quenching being similar to the $*\left[\mathrm{Ru}(\mathrm{bpz})_{3}\right]^{2+3} \mathrm{MLCT}$ excited state, Table 2 . The title trimetallics are strong oxidizers in their ${ }^{3} \mathrm{MLCT}$ excited state with $E\left({ }^{*} \mathrm{CAT}^{\mathrm{n}+} / \mathrm{CAT}^{(\mathrm{n}-1)+}\right)$ ranging from $1.35-1.46 \mathrm{~V}$ vs. $\mathrm{Ag} / \mathrm{AgCl}$ providing the driving force to oxidize many molecules including some water oxidation catalysts.

Table 2. Excited state reduction potentials and thermodynamic driving force for excited state

\begin{tabular}{|c|c|c|c|c|c|}
\hline Complex & $\begin{array}{c}E\left({ }^{*} \mathrm{CAT}^{\mathrm{n}+} / \mathrm{CAT}^{(\mathrm{n}-1)+}\right) \\
{ }^{3} \operatorname{MLCT}(\mathrm{V})^{a}\end{array}$ & $\begin{array}{c}E\left({ }^{*} \mathrm{CAT}^{\mathrm{n}+} / \mathrm{CAT}^{(\mathrm{n}-1)+}\right) \\
{ }^{3} \mathrm{MMCT}(\mathrm{V})^{a}\end{array}$ & $\begin{array}{c}E_{\text {redox }} \\
{ }^{3} \mathbf{M L C T} \\
(\mathbf{V})^{b}\end{array}$ & $\begin{array}{c}E_{\text {redox }} \\
{ }^{3} \text { MMCT } \\
(V)^{b}\end{array}$ & $\begin{array}{c}\mathbf{k}_{\mathbf{q}}+\mathbf{k}_{2} \\
\left(\mathbf{M}^{-1} \mathbf{s}^{-1}\right)^{c}\end{array}$ \\
\hline$\left[\mathrm{Ru}(\mathrm{bpy})_{3}\right]^{2+e}$ & +0.82 & -- & -0.04 & -- & $7.1 \times 10^{7 d}$ \\
\hline$\left[\mathrm{Ru}(\mathrm{bpz})_{3}\right]^{2+f}$ & +1.50 & -- & +0.64 & -- & $8.4 \times 10^{9 d}$ \\
\hline$\left[\left\{(\mathrm{bpy})_{2} \mathrm{Ru}(\mathrm{dpp})\right\}_{2} \mathrm{RhCl}_{2}\right]^{5+}$ & +1.35 & +0.94 & +0.49 & +0.08 & $2.5 \times 10^{9}$ \\
\hline$\left[\left\{(\mathrm{bpy})_{2} \mathrm{Ru}(\mathrm{dpp})\right\}_{2} \mathrm{RhBr}_{2}\right]^{5+}$ & +1.38 & +0.99 & +0.52 & +0.13 & $3.2 \times 10^{9}$ \\
\hline$\left[\left\{(\text { phen })_{2} \mathrm{Ru}(\mathrm{dpp})\right\}_{2} \mathrm{RhCl}_{2}\right]^{5+}$ & +1.41 & +1.01 & +0.55 & +0.15 & $3.9 \times 10^{9}$ \\
\hline$\left[\left\{(\text { phen })_{2} \mathrm{Ru}(\mathrm{dpp}){ }_{2} \mathrm{RhBr}_{2}\right]^{5+}\right.$ & +1.44 & +1.05 & +0.58 & +0.19 & $5.9 \times 10^{9}$ \\
\hline$\left[\left\{\left(\mathrm{Ph}_{2} \mathrm{phen}\right){ }_{2} \mathrm{Ru}(\mathrm{dpp})\right\}_{2} \mathrm{RhCl}_{2}\right]^{5+}$ & +1.43 & +1.04 & +0.57 & +0.18 & $1.5 \times 10^{9}$ \\
\hline$\left[\left\{\left(\mathrm{Ph}_{2} \text { phen }\right)_{2} \mathrm{Ru}(\mathrm{dpp})\right\}_{2} \mathrm{RhBr}_{2}\right]^{5+}$ & +1.46 & +1.09 & +0.60 & +0.23 & $2.9 \times 10^{9}$ \\
\hline
\end{tabular}
reductive quenching of $\left[\left\{(\mathrm{TL})_{2} \mathrm{Ru}(\mathrm{dpp})\right\}_{2} \mathrm{RhX}_{2}\right]^{5+}$ supramolecular complexes.

${ }^{a}$ Potential in $\mathrm{V}$ vs. $\mathrm{Ag} / \mathrm{AgCl}, E\left({ }^{*} \mathrm{CAT}^{\mathrm{n}+} / \mathrm{CAT}^{(\mathrm{n}-1)+}\right)$ is the excited state reduction potential;

${ }^{b}$ Thermodynamic driving force calculated by measuring the difference between the excited state reduction potential of the complex and the ground state oxidation potential of the electron donor DMA $\left(\mathrm{DMA}^{0 /+}=0.86 \mathrm{~V} v s\right.$. $\left.\mathrm{Ag} / \mathrm{AgCl}\right){ }^{\mathrm{c}}{ }^{\mathrm{c}}$ Rate constant for quenching of ${ }^{3} \mathrm{MLCT}$ excited state through bimolecular interactions with the electron donor DMA; ${ }^{\mathrm{d}}$ Values are reported $\mathrm{k}_{\mathrm{q}}$ rate constants; ${ }^{\mathrm{e}}$ From reference [33]; ${ }^{\mathrm{f}}$ From reference [34]. 
A Stern-Volmer analysis was performed to observe the ${ }^{3}$ MLCT emission quenching of the trimetallic complexes using the electron donor DMA, Figure 6. All complexes show a linear Stern-Volmer relationship with reduction of the ${ }^{3}$ MLCT excited state emission intensity varying linearly with increasing [DMA]. Equation 18 relates the ratio of the intensity of ${ }^{3}$ MLCT emission in the absence $\left(\mathrm{I}_{0}\right)$ and presence $(\mathrm{I})$ of DMA to the concentration of DMA added:

$$
\frac{\mathrm{I}_{0}}{\mathrm{I}}=\frac{\left(\mathrm{k}_{\mathrm{q}}+\mathrm{k}_{2}\right)[\mathrm{DMA}]}{\left(\mathrm{k}_{1}+\mathrm{k}_{\mathrm{et}}\right)}+1
$$

where $\mathrm{k}_{1}=\mathrm{k}_{\mathrm{r}}+\mathrm{k}_{\mathrm{nr}}$ [38]. The slope of the Stern-Volmer quenching plot contains the rate constant for quenching by DMA of the ${ }^{3}$ MLCT state via bimolecular deactivation $\left(\mathrm{k}_{2}\right)$ or photoreduction $\left(\mathrm{k}_{\mathrm{q}}\right)$ to form the reduced $\mathrm{Rh}(\mathrm{II})$ photoproduct. From these experiments, the values corresponding to the deactivation of the ${ }^{3}$ MLCT excited state through bimolecular interactions with DMA $\left(\mathrm{k}_{\mathrm{q}}+\mathrm{k}_{2}\right)$ were obtained and vary from $1.5 \times 10^{9} \mathrm{M}^{-1} \mathrm{~s}^{-1}$ to $5.9 \times 10^{9} \mathrm{M}^{-1} \mathrm{~s}^{-1}$, indicative of efficient quenching of the ${ }^{3}$ MLCT excited state, Table 2. Competing pathways for deactivation of the ${ }^{3}$ MLCT excited state are radiative $\left(\mathrm{k}_{\mathrm{r}}\right)$ and non-radiative $\left(\mathrm{k}_{\mathrm{nr}}\right)$ decay to the ${ }^{1} \mathrm{GS}$ and intramolecular electron transfer $\left(\mathrm{k}_{\mathrm{et}}\right)$ to populate the ${ }^{3} \mathrm{MMCT}$ excited state. The calculated rate constants for these unimolecular deactivation pathways (Table 1) are substantially smaller than the DMA bimolecular quenching rate constants. This observation suggests that in the presence of DMA, the dominating pathways of deactivation from the ${ }^{3}$ MLCT excited state involve bimolecular quenching with the electron donor. While this Stern-Volmer analysis of the ${ }^{3}$ MLCT excited state quenching does not permit the independent calculation of $\mathrm{k}_{\mathrm{q}}$ and $\mathrm{k}_{2}$, photochemical product formation studies enable extraction of the $\mathrm{k}_{\mathrm{q}}$ value and the subsequent value of $\mathrm{k}_{2}$ is obtained below.

Figure 6. Emission quenching of $\left[\left\{(\text { phen })_{2} \mathrm{Ru}(\mathrm{dpp})\right\}_{2} \mathrm{RhCl}_{2}\right]^{5+}{ }^{3} \mathrm{MLCT}$ excited state using DMA sacrificial electron donor. Inset: Stern-Volmer plot depicting linear relationship of emission quenching and DMA concentration.

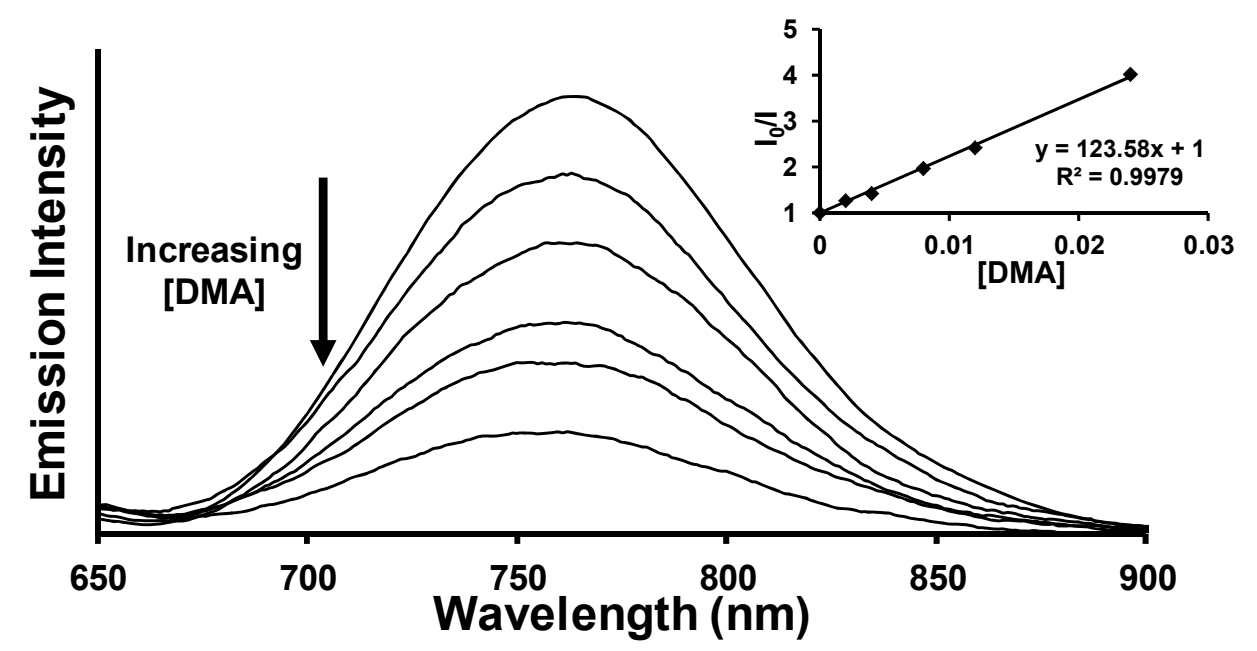

\subsection{Product Formation}

The photochemical reduction of the $\left[\left\{(\mathrm{TL})_{2} \mathrm{Ru}(\mathrm{dpp})\right\}_{2} \mathrm{RhX}_{2}\right]^{5+}$ complexes by two electrons to produce $\mathrm{Rh}(\mathrm{I})$ species is expected to proceed through a $\mathrm{Rh}(\mathrm{II})$ intermediate. The spectroscopic change 
upon reduction from $\mathrm{Rh}(\mathrm{III})$ to $\mathrm{Rh}(\mathrm{II})$ to $\mathrm{Rh}(\mathrm{I})$ proceeds with a smooth shift to higher energy of the $\operatorname{Ru}(\mathrm{d} \pi) \rightarrow \operatorname{dpp}\left(\pi^{*}\right)$ CT transition. This photoproduct can be generated through excited state reductive quenching of the ${ }^{3} \mathrm{MLCT}$ or ${ }^{3} \mathrm{MMCT}$ excited states, or a combination of both states as depicted in Equations 11 and 15. Monitoring changes to the electronic absorption spectra over time while photolyzing the $\left[\left\{(\mathrm{TL})_{2} \mathrm{Ru}(\mathrm{dpp})\right\}_{2} \mathrm{RhX}_{2}\right]^{5+}$ complexes in the presence of varied concentrations of DMA provides a means of analyzing the rate constants for photoreduction of the $\mathrm{Rh}$ center. The Stern-Volmer kinetic relationship for excited state reactivity in this forum is applied to analyze the kinetics of the ${ }^{3} \mathrm{MLCT}$ or ${ }^{3} \mathrm{MMCT}$ bimolecular photoreduction using Equations 19 and 20. A Stern-Volmer analysis of the quantum yield for product formation was undertaken to assist in exploring the role that ${ }^{3} \mathrm{MLCT}$ and ${ }^{3} \mathrm{MMCT}$ excited states have on supramolecule reduction. Upon photolysis with visible light $(\lambda=470 \mathrm{~nm})$, the lowest energy $\mathrm{Ru}(\mathrm{d} \pi) \rightarrow \mathrm{dpp}\left(\pi^{*}\right) \mathrm{CT}$ transition $c a$. $518 \mathrm{~nm}$ decreases intensity with a concurrent shift to higher energy $c a$. $440 \mathrm{~nm}$. The change in absorbance of these two transitions at 518 and $440 \mathrm{~nm}$ are monitored as a function of time and the data extrapolated to $t=0$ for analysis, Figure $7 \mathrm{~A}$. Figures $7 \mathrm{~B}$ and $7 \mathrm{C}$ correspond to the overall quantum yield of reduced $\mathrm{Rh}$ product formation.

Figure 7. (A) Photochemical reduction of $\left[\left\{(\text { phen })_{2} \mathrm{Ru}(\mathrm{dpp})\right\}_{2} \mathrm{RhCl}_{2}\right]^{5+}$ using DMA sacrificial electron donor to generate reduced $\mathrm{Rh}$ photoproduct; (B) Analysis showing non-linear relationship of product formation with respect to photolysis time at varying DMA concentrations; (C) Stern-Volmer plot depicting linear relationship between reciprocal of product formation and reciprocal of DMA concentration.
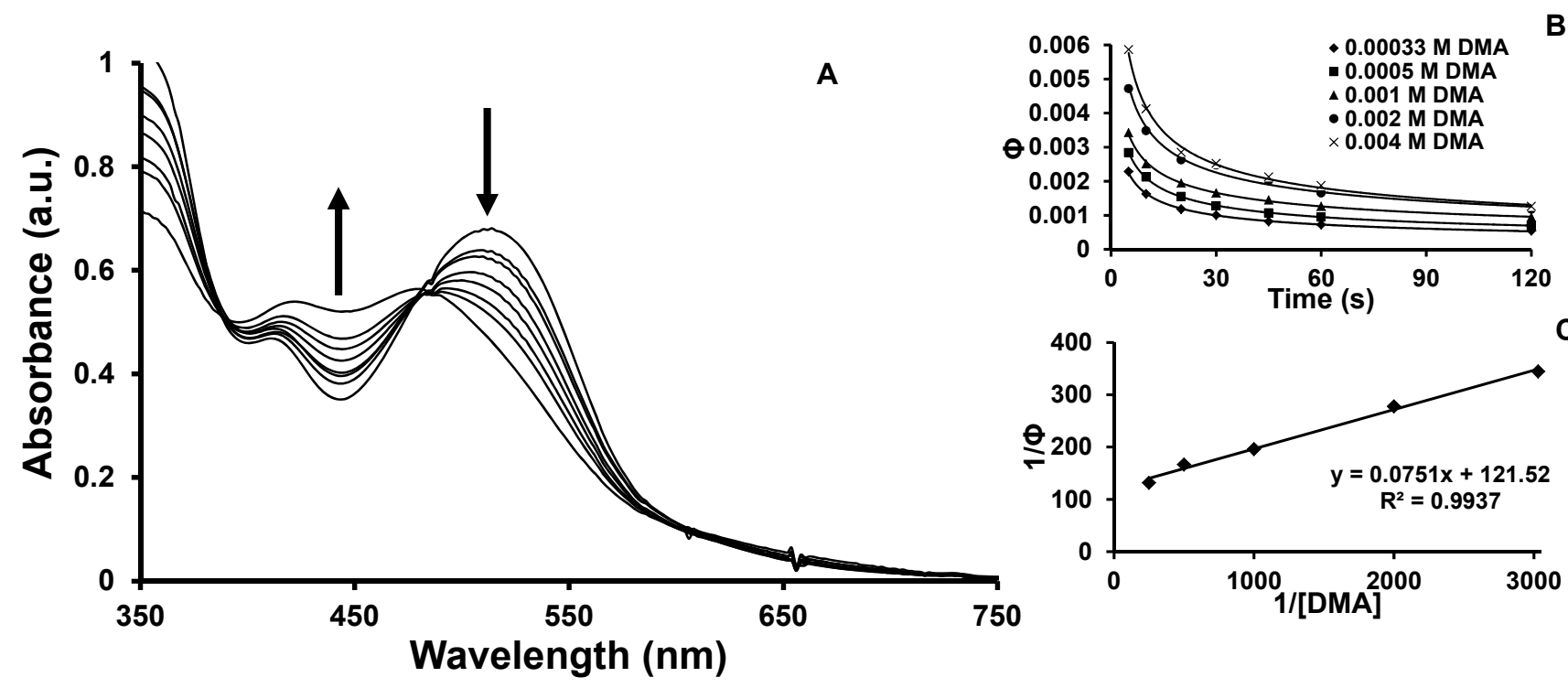

Product formation to generate the reduced supramolecules can occur from the ${ }^{3} \mathrm{MLCT}$ or ${ }^{3} \mathrm{MMCT}$ excited states. Kinetic analysis first considers product formation from the ${ }^{3}$ MLCT state. The $\operatorname{Ru}(\mathrm{d} \pi) \rightarrow \operatorname{dpp}\left(\pi^{*}\right){ }^{3}$ MLCT excited state can deactivate through unimolecular deactivation to the ground state $\left(\mathrm{k}_{1}\right)$, bimolecular deactivation through interaction with DMA $\left(\mathrm{k}_{2}\right)$, intramolecular electron transfer to populate the ${ }^{3} \mathrm{MMCT}$ state $\left(\mathrm{k}_{\mathrm{et}}\right)$, or reductive quenching by DMA to produce the reduced species $\left(\mathrm{k}_{\mathrm{q}}\right)$. Equation 19 relates the quantum yield of formation of the reduced species ( $\left.\Phi_{\text {product }}\right)$ to [DMA]. 


$$
\frac{1}{\Phi_{\text {product }}}=\frac{\mathbf{k}_{\mathbf{1}}+\mathbf{k}_{\mathrm{et}}}{\mathbf{k}_{\mathbf{q}}[\mathrm{DMA}]}+\frac{\mathbf{k}_{\mathbf{q}}+\mathbf{k}_{\mathbf{2}}}{\mathbf{k}_{\mathbf{q}}}
$$

Plotting $1 / \Phi_{\text {product }} v$ s. $1 /[\mathrm{DMA}]$ gives a linear relationship, with a slope of $\left(\mathrm{k}_{1}+\mathrm{k}_{\mathrm{et}}\right) / \mathrm{k}_{\mathrm{q}}$ and an intercept of $\left(\mathrm{k}_{\mathrm{q}}+\mathrm{k}_{2}\right) / \mathrm{k}_{\mathrm{q}}$. The rate constant for unimolecular deactivation, $\mathrm{k}_{1}$, is the sum of $\mathrm{k}_{\mathrm{r}}$ and $\mathrm{k}_{\mathrm{nr}}$ and has been determined above. The rate constant for intramolecular electron transfer, $\mathrm{k}_{\mathrm{et}}$, was obtained from our above emission analysis. This allows the determination of $\mathrm{k}_{\mathrm{q}}$ and $\mathrm{k}_{2}$, Table 3 .

Table 3. Rate constants for $\mathrm{Rh}$ reduction for $\left[\left\{(\mathrm{TL})_{2} \mathrm{Ru}(\mathrm{dpp})\right\}_{2} \mathrm{RhX}_{2}\right]\left(\mathrm{PF}_{6}\right)_{5}$ supramolecular complexes from the ${ }^{3}$ MLCT and ${ }^{3}$ MMCT excited states.

\begin{tabular}{|c|c|c|c|c|}
\hline Complex & $k_{q}\left(10^{8} M^{-1} s^{-1}\right)^{a}$ & $k_{2}\left(10^{9} M^{-1} s^{-1}\right)^{b}$ & $\Phi_{3 \mathrm{MMCT}}{ }^{c}$ & $\mathbf{k}_{4} / \mathbf{k}_{\mathrm{q} 2}{ }^{d}$ \\
\hline$\left[\left\{(\mathrm{bpy})_{2} \mathrm{Ru}(\mathrm{dpp})\right\}_{2} \mathrm{RhCl}_{2}\right]^{5+}$ & 2.1 & 2.3 & 0.74 & 0.094 \\
\hline$\left[\left\{(\mathrm{bpy})_{2} \mathrm{Ru}(\mathrm{dpp})\right\}_{2} \mathrm{RhBr}_{2}\right]^{5+}$ & 3.5 & 2.9 & 0.77 & 0.066 \\
\hline$\left[\left\{(\mathrm{phen}){ }_{2} \mathrm{Ru}(\mathrm{dpp}){ }_{2} \mathrm{RhCl}_{2}\right]^{5+}\right.$ & 3.8 & 3.5 & 0.79 & 0.060 \\
\hline$\left[\left\{(\text { phen })_{2} \operatorname{Ru}(\mathrm{dpp})\right\}_{2} \mathrm{RhBr}_{2}\right]^{5+}$ & 4.3 & 5.5 & 0.82 & 0.063 \\
\hline$\left[\left\{\left(\mathrm{Ph}_{2} \text { phen }\right)_{2} \mathrm{Ru}(\mathrm{dpp})\right\}_{2} \mathrm{RhCl}_{2}\right]^{5+}$ & 2.5 & 1.3 & 0.73 & 0.056 \\
\hline$\left[\left\{\left(\mathrm{Ph}_{2} \text { phen }\right)_{2} \mathrm{Ru}(\mathrm{dpp})\right\}_{2} \mathrm{RhBr}_{2}\right]^{5+}$ & 4.2 & 2.4 & 0.79 & 0.047 \\
\hline
\end{tabular}

${ }^{a}$ Rate constant for reductive quenching of the ${ }^{3} \mathrm{MLCT}$ excited state with DMA; ${ }^{b}$ Rate constant for bimolecular deactivation through interaction with DMA; ${ }^{c}$ Quantum yield of formation of the ${ }^{3} \mathrm{MMCT}$ excited state; ${ }^{d}$ Ratio of the rate constant for back electron transfer from the ${ }^{3} \mathrm{MMCT}$ excited state to the rate constant for reduction quenching from the ${ }^{3} \mathrm{MMCT}$ state with DMA.

Reduction of the $\left[\left\{(\mathrm{TL})_{2} \mathrm{Ru}(\mathrm{dpp})\right\}_{2} \mathrm{RhX}_{2}\right]^{5+}$ can also occur from the ${ }^{3} \mathrm{MMCT}$ excited state. The $\mathrm{Ru}(\mathrm{d} \pi) \rightarrow \mathrm{Rh}\left(\sigma^{*}\right){ }^{3} \mathrm{MMCT}$ excited state can undergo multiple deactivation pathways including unimolecular deactivation $\left(\mathrm{k}_{4}\right)$, bimolecular deactivation with DMA $\left(\mathrm{k}_{3}\right)$ and reductive quenching of the excited state by DMA to produce the singly reduced species $\left(\mathrm{k}_{\mathrm{q} 2}\right)$. The efficiency of $\mathrm{Rh}(\mathrm{II})$ product formation from the ${ }^{3} \mathrm{MMCT}$ state depends on the efficiency of populating the ${ }^{3} \mathrm{MMCT}$ state $\left(\Phi_{3 \mathrm{MMCT}}\right)$. Equation 20 relates the quantum yield of formation of the reduced species ( $\Phi_{\text {product }}$ ) from the ${ }^{3} \mathrm{MMCT}$ excited state to [DMA].

$$
\frac{1}{\Phi_{\text {product }}}=\left(\frac{1}{\Phi_{3_{\mathrm{MMCT}}}}\right)\left(\frac{\mathrm{k}_{4}}{\mathrm{k}_{\mathrm{q} 2}[\mathrm{DMA}]}\right)+\frac{\mathrm{k}_{\mathrm{q} 2}+\mathrm{k}_{3}}{\mathrm{k}_{\mathrm{q} 2}}
$$

A plot of $1 / \Phi_{\text {product }}$ and $1 /[\mathrm{DMA}]$ is linear with a slope of $\left(1 / \Phi_{3 \mathrm{MMCT}}\right)\left(\mathrm{k}_{4} / \mathrm{k}_{\mathrm{q} 2}\right)$ and an intercept of $\left(\mathrm{k}_{\mathrm{q} 2}+\mathrm{k}_{3}\right) / \mathrm{k}_{\mathrm{q} 2}$. Values obtained for $\Phi_{3 \mathrm{MMCT}}$ and $\mathrm{k}_{4} / \mathrm{k}_{\mathrm{q} 2}$ from these analyses are presented in Table 3 . The $\Phi_{3 \text { MMCT }}$ is given by the ratio of $k_{\text {et }}$ to $k_{r}+k_{n r}$ determined from the emission of the $\left[\left\{(\mathrm{TL})_{2} \mathrm{Ru}(\mathrm{dpp})\right\}_{2} \mathrm{RhX}_{2}\right]^{5+}$ complexes above. A direct measure of $\mathrm{k}_{4}$ is not provided so this analysis gives a ratio of $\mathrm{k}_{4} / \mathrm{k}_{\mathrm{q} 2}$. The $\mathrm{Ru}(\mathrm{II}), \mathrm{Rh}(\mathrm{III})$ bimetallic complex [( $\mathrm{Me}_{2}$ phen $)_{2} \mathrm{Ru}\left(\mathrm{Mebpy}-\mathrm{CH}_{2} \mathrm{CH}_{2}-\mathrm{Mebpy}\right)$ $\left.\mathrm{Rh}\left(\mathrm{Me}_{2} \text { bpy }\right)_{2}\right]^{5+}\left(\mathrm{Me}_{2}\right.$ phen = 4,7-dimethyl-1,10-phenanthroline; $\mathrm{Me}_{2}$ bpy = 4,4'-dimethyl-2,2'-bipyridine $)$ was studied via transient spectroscopy to provide $\mathrm{k}_{4}=7.1 \times 10^{9} \mathrm{~s}^{-1}$ [25]. This system shows a $\mathrm{k}_{\mathrm{et}}$ to populate the ${ }^{3} \mathrm{MMCT}$ state of $1.4 \times 10^{7} \mathrm{~s}^{-1}$, similar in magnitude to our systems. The rate of back electron transfer from $\mathrm{Rh}(\mathrm{II})$ to $\mathrm{Ru}(\mathrm{III})$ to generate the ground state from the ${ }^{3} \mathrm{MMCT}$ state, $\mathrm{k}_{4}$, is expected to be fast for our complexes given the direct dpp coupling of the Ru and Rh centers in our systems vs. the Mebpy- $\mathrm{CH}_{2} \mathrm{CH}_{2}$-Mebpy linker in the previously reported system. Assuming $\mathrm{k}_{4}$ for our systems is $\geq 7.1 \times 10^{9} \mathrm{~s}^{-1}$, this calculates $\mathrm{k}_{\mathrm{q} 2}$ values of $c a .10^{11} \mathrm{M}^{-1} \mathrm{~s}^{-1}$, an unreasonably large number. 
This suggests supramolecule reduction occurs primarily out of the ${ }^{3} \mathrm{MLCT}$ state in our systems. The direct analysis of the contribution of the ${ }^{3} \mathrm{MMCT}$ state to product formation is not accessible via these methods. The analysis herein does highlight that any photoreduction via the ${ }^{3} \mathrm{MMCT}$ state would occur on the picosecond time scale.

Several pathways of deactivation of the ${ }^{3} \mathrm{MLCT}$ state impact the trimetallic complexes' ability to function as PECs and ultimately as solar energy conversion catalysts for water reduction. Deactivation of the ${ }^{3}$ MLCT state to the GS is a dominant pathway both via non-radiative $\left(k_{n r}\right)$, radiative $\left(k_{r}\right)$, and bimolecular deactivation $\left(\mathrm{k}_{2}\right)$. The quenching of the ${ }^{3} \mathrm{MLCT}$ excited state of the trimetallic complexes $\left[\left\{(\mathrm{TL})_{2} \mathrm{Ru}(\mathrm{dpp})\right\}_{2} \mathrm{RhX}_{2}\right]^{5+}$ in $\mathrm{CH}_{3} \mathrm{CN}$ at $\mathrm{RT}$ is very efficient with rate constants $1-6 \times 10^{9} \mathrm{M}^{-1} \mathrm{~s}^{-1}$ at the diffusion control limit. The rate of the associated photoreduction of the trimetallics by DMA is less, 2-4 $\times 10^{8} \mathrm{M}^{-1} \mathrm{~s}^{-1}$, indicative of the often efficient back electron transfer prior to cage escape in Ru-polyazine systems. Nonetheless photoreduction occurs at a significant rate, $10^{8} \mathrm{M}^{-1} \mathrm{~s}$, providing for the rapid conversion of the $\mathrm{Rh}$ (III) supramolecules to reduced species. The variation of the halide bound to the $\mathrm{Rh}$ from $\mathrm{Cl}$ to $\mathrm{Br}$ provides for enhanced rates of photoreduction independent of TL (bpy, phen or $\mathrm{Ph}_{2}$ phen). TL variation impacts observed rates as well. Emission quenching by DMA $\left(\mathrm{k}_{\mathrm{q}}+\mathrm{k}_{2}\right)$ is most efficient for phen complexes with $\mathrm{Ph}_{2}$ phen providing for the lowest rate of DMA quenching of the ${ }^{3}$ MLCT excited state. The enhanced rate of quenching of the ${ }^{3}$ MLCT state by DMA for TL $=$ phen may be a result of efficient $\pi-\pi$ interaction of the phen TL with the DMA electron donor placing the DMA near the Ru center.

The above $\mathrm{Ru}(\mathrm{II}), \mathrm{Rh}(\mathrm{III}), \mathrm{Ru}(\mathrm{II})$ trimetallic complexes are photocatalysts in the reduction of $\mathrm{H}_{2} \mathrm{O}$ to $\mathrm{H}_{2}$, Table 4. The photosystems containing $65 \mu \mathrm{M}$ photocatalyst, $1.5 \mathrm{M}$ DMA, $0.62 \mathrm{M} \mathrm{H}_{2} \mathrm{O}$ and $0.11 \mathrm{mM}$ $\left[\mathrm{CF}_{3} \mathrm{SO}_{3}{ }^{-}\right]\left[\mathrm{DMAH}^{+}\right]$in $\mathrm{CH}_{3} \mathrm{CN}$ were photolyzed for $5 \mathrm{~h}$ using a $470 \mathrm{~nm}$ LED light source. Turnover numbers (TON) were measured as the mol of $\mathrm{H}_{2}$ produced per mol of $\mathrm{Rh}$ catalytic center. The quantum efficiency of $\mathrm{H}_{2}\left(\Phi_{\mathrm{H} 2}\right)$ was measured as mol of $\mathrm{H}_{2}$ produced per mol of photons, multiplied by two given the formation of $\mathrm{H}_{2}$ is a two photon and two electron process within our molecular architecture. Halide variation from $\mathrm{Cl}$ to $\mathrm{Br}$ displays more efficient $\mathrm{H}_{2}$ production as suggested by the enhanced rates of reduced $\mathrm{Rh}$ product formation. Photocatalysts where $\mathrm{TL}=$ phen display the lowest amount of $\mathrm{H}_{2}$, consistent with the larger rate constant for bimolecular deactivation of the ${ }^{3}$ MLCT excited state $\left(\mathrm{k}_{2}\right)$ inhibiting efficient formation of the reduced $\mathrm{Rh}$ species. While photocatalysts with $\mathrm{TL}=\mathrm{Ph}_{2}$ phen outperform $\mathrm{TL}=$ bpy or phen systems, the observed excited state rate constants do not vary greatly, suggesting additional factors impact photocatalytic functioning. The steric demands of the $\mathrm{Ph}_{2}$ phen ligand may provide protection of the photoreduced $\mathrm{Rh}(\mathrm{I})$ center, decreasing unfavorable side reactions and therefore enhancing $\mathrm{H}_{2}$ production. 
Table 4. Photocatalytic $\mathrm{H}_{2}$ Production from Water using $\left[\left\{(\mathrm{TL})_{2} \mathrm{Ru}(\mathrm{dpp})\right\}_{2} \mathrm{RhX}_{2}\right]\left(\mathrm{PF}_{6}\right)_{5}$ Supramolecular Complexes.

\begin{tabular}{lccc}
\hline Complex $^{\boldsymbol{a}}$ & $\mathbf{H}_{\mathbf{2}}(\boldsymbol{\mu} \mathbf{m o l})$ & $\mathbf{T O N}^{\boldsymbol{b}}$ & $\boldsymbol{\Phi}_{\mathbf{H} 2}{ }^{\boldsymbol{c}}$ \\
\hline$\left[\left\{(\mathrm{bpy})_{2} \mathrm{Ru}(\mathrm{dpp})\right\}_{2} \mathrm{RhCl}_{2}\right]^{5+}$ & $7.2 \pm 0.7$ & $25 \pm 2$ & 0.0025 \\
{$\left[\left\{(\mathrm{bpy})_{2} \mathrm{Ru}(\mathrm{dpp})\right\}_{2} \mathrm{RhBr}_{2}\right]^{5+}$} & $8.9 \pm 0.4$ & $31 \pm 1$ & 0.0055 \\
{$\left[\left\{(\mathrm{phen})_{2} \mathrm{Ru}(\mathrm{dpp})\right\}_{2} \mathrm{RhCl}_{2}\right]^{5+}$} & $4.1 \pm 0.2$ & $14 \pm 1$ & 0.0017 \\
{$\left[\left\{(\mathrm{phen})_{2} \mathrm{Ru}(\mathrm{dpp})\right\}_{2} \mathrm{RhBr}_{2}\right]^{5+}$} & $5.9 \pm 0.7$ & $20 \pm 3$ & 0.0026 \\
{$\left[\left\{\left(\mathrm{Ph}{ }_{2} \text { phen }\right)_{2} \mathrm{Ru}(\mathrm{dpp})\right\}_{2} \mathrm{RhCl}_{2}\right]^{5+}$} & $33 \pm 3$ & $110 \pm 10$ & 0.012 \\
{$\left[\left\{\left(\mathrm{Ph}{ }_{2} \text { phen }\right)_{2} \mathrm{Ru}(\mathrm{dpp})\right\}_{2} \mathrm{RhBr}_{2}\right]^{5+}$} & $40 \pm 4$ & $140 \pm 10$ & 0.019 \\
\hline
\end{tabular}

${ }^{a}$ Results correspond to $5 \mathrm{~h}$ photolysis time using $470 \mathrm{~nm}$ LED light source (light flux $=2.36 \pm 0.05$ $\times 10^{19}$ photons $/ \mathrm{min}$; solution volume $=4.5 \mathrm{~mL}$; head space volume $\left.=15.5 \mathrm{~mL}\right) ;{ }^{b} \mathrm{TON}=$ turnover numbers $=\mathrm{mol} \mathrm{H}_{2}$ produced per mol Rh catalytic center; ${ }^{c} \Phi_{\mathrm{H} 2}=$ maximum quantum efficiency of $\mathrm{H}_{2}$ formation.

\section{Experimental Section}

\subsection{Materials}

All solvents and chemicals were used as received unless otherwise stated. Spectral grade acetonitrile was purchased from Burdick and Jackson. Redistilled $N, N$-dimethylaniline was purchased from Aldrich Chemical Company. The complexes $\left[\left\{(\text { bpy })_{2} \mathrm{Ru}(\mathrm{dpp})\right\}_{2} \mathrm{RhCl}_{2}\right]\left(\mathrm{PF}_{6}\right)_{5}[11],\left[\left\{(\mathrm{bpy})_{2} \mathrm{Ru}(\mathrm{dpp})\right\}_{2}\right.$ $\left.\mathrm{RhBr}_{2}\right]\left(\mathrm{PF}_{6}\right)_{5} \quad[12], \quad\left[\left\{(\mathrm{phen})_{2} \mathrm{Ru}(\mathrm{dpp})\right\}_{2} \mathrm{RhCl}_{2}\right]\left(\mathrm{PF}_{6}\right)_{5} \quad[13], \quad\left[\left\{(\mathrm{phen})_{2} \mathrm{Ru}(\mathrm{dpp})\right\}_{2} \mathrm{RhBr}_{2}\right]\left(\mathrm{PF}_{6}\right)_{5} \quad[16]$, $\left[\left\{\left(\mathrm{Ph}_{2} \text { phen }\right)_{2} \mathrm{Ru}(\mathrm{dpp})\right\}_{2} \mathrm{RhCl}_{2}\right]\left(\mathrm{PF}_{6}\right)_{5}[15]$ and $\left[\left\{\left(\mathrm{Ph}_{2} \mathrm{phen}\right)_{2} \mathrm{Ru}(\mathrm{dpp})\right\}_{2} \mathrm{RhBr}_{2}\right]\left(\mathrm{PF}_{6}\right)_{5}$ [15] were prepared as reported.

\subsection{Methods}

\subsubsection{Electronic Absorption Spectroscopy}

Electronic absorption spectra were measured using a Hewlett-Packard 8452A diode array spectrophotometer with $2 \mathrm{~nm}$ resolution. Spectra were recorded at room temperature in spectral grade acetonitrile using a $1 \mathrm{~cm}$ path length cylindrical quartz cuvette (Starna Cells, Inc., Atascadero, CA, USA).

\subsubsection{Steady State Luminescence Spectroscopy}

The room temperature steady state emission spectra were measured in spectral grade acetonitrile using a $1 \mathrm{~cm}$ path length quartz cuvette equipped with a screw top (Starna Cells, Inc.; Atascadero, CA, USA). The instrument used to record the spectra was a QuantaMaster Model QM-200-45E fluorimeter from Photon Technologies International, Inc. The excitation source was a water-cooled $150 \mathrm{~W}$ Xenon arc lamp with the corresponding emission collected at a $90^{\circ}$ angle using a thermoelectrically cooled Hamamatsu 1527 photomultiplier tube operating in photon counting mode with $0.25 \mathrm{~nm}$ resolution. The emission monochromator contained a Czerny-Turner style grating monochromator set to 1,200 line $/ \mathrm{mm}$ $750 \mathrm{~nm}$ blaze. 


\subsubsection{Excited State Emission Quenching}

Stock solutions of each trimetallic complex were prepared using spectral grade acetonitrile. Sample solutions were composed of a fixed final concentration of trimetallic complex $(\sim 30 \mu \mathrm{M})$ in a $1 \mathrm{~cm}$ quartz cuvette with increasing final concentrations of DMA $\left((2.4-0.2) \times 10^{-2} \mathrm{M}\right)$ added to a new sample. DMA was injected into the sample in the dark using a syringe just prior to excitation from the $150 \mathrm{~W}$ Xe arc lamp light source. The steady state emission spectrum for each sample was obtained and a Stern-Volmer plot of $\mathrm{I}_{0} / \mathrm{I} v s$. [DMA] was generated and analyzed [38].

\subsubsection{Photochemical Product Formation}

Sample solutions were composed of a fixed concentration of trimetallic complex $(\sim 25 \mu \mathrm{M})$ with increasing final concentrations of DMA $\left((4.0-0.33) \times 10^{-3} \mathrm{M}\right)$ added to each sample. The electronic absorption spectra were measured after photolysis on a $470 \mathrm{~nm}$ LED array designed and constructed locally (flux $=2.83 \times 10^{19}$ photons $/ \mathrm{min}$ ) [40]. Data were plotted and extrapolated to zero time.

\subsubsection{Photocatalytic Hydrogen Production}

The photocatalytic hydrogen production experiments were performed using modifications of previously reported conditions [14]. The trimetallic stock solutions $(92 \mu \mathrm{M})$ in $\mathrm{CH}_{3} \mathrm{CN}$ were combined with water (acidified to $\mathrm{pH} 2$ using $\mathrm{CF}_{3} \mathrm{SO}_{3} \mathrm{H}$ ) in air tight photolysis reaction cells that were deoxygenated using argon gas. The electron donor DMA was deoxygenated separately and injected into the reaction cells just prior to photolysis (final conditions: [trimetallic] $=65 \mu \mathrm{M}$; [DMA] $=1.5 \mathrm{M}$; $\left[\mathrm{H}_{2} \mathrm{O}\right]=0.62 \mathrm{M} ;\left[\mathrm{DMAH}^{+}\right]\left[\mathrm{CF}_{3} \mathrm{SO}_{3}{ }^{-}\right]=0.11 \mathrm{mM}$; solution volume $=4.5 \mathrm{~mL}$; headspace $=15.5 \mathrm{~mL}$ ). The reaction cells were photolyzed from the bottom using a $470 \mathrm{~nm}$ LED array constructed in our laboratory (light flux $=(2.36 \pm 0.05) \times 10^{19}$ photons $/ \mathrm{min}$; power $\left.=200 \mathrm{~mW}\right)$ [40]. The amount of hydrogen produced was monitored in real-time using a HY-OPTIMA ${ }^{\mathrm{TM}} 700$ in-line process solid state hydrogen sensor from H2scan connected to the photolysis reaction cell. The sensor was calibrated by injecting known quantities of hydrogen into the photolysis cells and generating a calibration curve. The functioning of the sensor was verified by injecting a $100 \mu \mathrm{L}$ sample from the reaction cell's headspace into a series 580 GOW-MAC gas chromatograph equipped with a rhenium-tungsten thermal conductivity detector and a $5 \AA$ molecular sieves column using ultra-high purity argon gas. The gas chromatograph signal was amplified with a Vernier Software instrument amplifier and recorded using Logger Pro 3.4.5 software. The gas chromatograph was calibrated for hydrogen signal sensitivity by injecting known amounts of hydrogen gas and generating a calibration curve. The reported value for hydrogen production is the average of three experiments.

\section{Conclusions}

The kinetic analysis shows that both TL and halide bound to Rh impacts observed excited state dynamics. Variation of TL and halide bound to Rh impacts rates of reactions from the formally $\mathrm{Ru} \rightarrow \mathrm{dpp} \mathrm{CT}$ excited states. The ${ }^{3} \mathrm{MLCT}$ states are longest lived for $\mathrm{TL}=\mathrm{Ph}_{2}$ phen and $\mathrm{X}=\mathrm{Cl}$ and shortest for $\mathrm{TL}=$ phen and $\mathrm{X}=\mathrm{Br}$. The rate of intramolecular electron transfer, $\mathrm{k}_{\mathrm{et}}$, to generate the 
${ }^{3} \mathrm{MMCT}$ state is largest when $\mathrm{TL}=$ phen and $\mathrm{X}=\mathrm{Br}$ and smallest with $\mathrm{TL}=\mathrm{Ph}_{2}$ phen and $\mathrm{X}=\mathrm{Cl}$. The $\Phi_{3 \mathrm{MMCT}}$ is large in all cases varying from $0.73-0.82$. Quenching of the ${ }^{3} \mathrm{MLCT}$ states is very efficient and all complexes studied undergo photoinitiated electron collection to produce the $\mathrm{Rh}(\mathrm{I})$ complex. Many of these systems are known photocatalysts for $\mathrm{H}_{2} \mathrm{O}$ reduction to produce $\mathrm{H}_{2}$ with high quantum yields and turnovers with respect to known supramolecular photocatalysts. The study of the rate of quenching of the ${ }^{3}$ MLCT state by DMA shows rapid quenching near the diffusion control limit. Photoreduction occurs at a rate, $\mathrm{k}_{\mathrm{q}}$, of $(2-4) \times 10^{8} \mathrm{M}^{-1} \mathrm{~s}^{-1}$, leading to rapid reduction of the supramolecules. This is consistent with the high thermodynamic driving force for reduction of the trimetallics by DMA which is thermodynamically favorable by $0.49-0.60 \mathrm{~V}$. Analysis of the kinetic requirements for photoreduction from the ${ }^{3} \mathrm{MLCT}$ and ${ }^{3} \mathrm{MMCT}$ states suggests photoreduction occurs primarily from the ${ }^{3} \mathrm{MLCT}$ state. These kinetic analyses provide considerable insight into the important excited state reactions of these $\mathrm{Ru}(\mathrm{II}), \mathrm{Rh}(\mathrm{III}), \mathrm{Ru}(\mathrm{II})$ supramolecular photoinitiated electron collectors, a class of molecules of interest as visible light induced photocatalysts for $\mathrm{H}_{2} \mathrm{O}$ reduction to $\mathrm{H}_{2}$.

\section{Acknowledgments}

The authors wish to acknowledge the Chemical Sciences, Geosciences and Biosciences Division, Office of Basic Energy Sciences, Office of Sciences, U.S. Department of Energy DE FG02-05ER15751 for their generous financial support of our research.

\section{References}

1. McDaniel, N.D.; Bernhard, S. Solar fuels: Thermodynamics, candidates, tactics, and figures of merit. Dalton Trans. 2010, 39, 10021-10030.

2. Teets, T.S.; Nocera, D.G. Photocatalytic hydrogen production. Chem. Commun. 2011, 47, 9268-9274.

3. Bard, A.J.; Fox, M.A. Artificial photosynthesis: Solar splitting of water to hydrogen and oxygen. Acc. Chem. Res. 1995, 28, 141-145.

4. Balzani, V.; Juris, A.; Venturi, M.; Campagna, S.; Serroni, S. Luminescent and redox-active polynuclear transition metal complexes. Chem. Rev. 1996, 96, 759-834.

5. Balzani, V.; Moggi, L.; Scandola, F. Supramolecular Photochemistry; Balzani, V., Ed.; Reidel: Dordrecht, The Netherlands, 1987; pp. 1-28.

6. Molnar, S.M.; Nallas, G.; Bridgewater, J.S.; Brewer, K.J. Photoinitiated electron collection in a mixed-metal trimetallic complex of the form $\left[\left\{(\mathrm{bpy})_{2} \mathrm{Ru}(\mathrm{dpb})\right]_{2} \mathrm{IrCl}_{2}\right\}\left(\mathrm{PF}_{6}\right)_{5}$ (bpy $=2,2^{\prime}$-bipyridine and $\mathrm{dpb}=2,3$-bis(2-pyridyl)benzoquinoxaline). J. Am. Chem. Soc. 1994, 116, 5206-5210.

7. Konduri, R.; Ye, H.; MacDonnell, F.M.; Serroni, S.; Campagna, S.; Rajeshwar, K. Ruthenium photocatalysts capable of reversibly storing up to four electrons in a single acceptor ligand: A step closer to artificial photosynthesis. Angew. Chem. Int. Ed. 2002, 41, 3185-3187.

8. Kim, M.-J.; Konduri, R.; Ye, H.; MacDonnell, F.M.; Puntoriero, F.; Serroni, S.; Campagna, S.; Holder, T.; Kinsel, G.; Rajeshwar, K. Dinuclear Ruthenium(II) polypyridyl complexes containing large, redox-active, aromatic bridging ligands: Synthesis, characterization, and intramolecular quenching of MLCT excited states. Inorg. Chem. 2002, 41, 2471-2476. 
9. Polyansky, D.; Cabelli, D.; Muckerman, J.T.; Fujita, E.; Koizumi, T.; Fukushima, T.; Wada, T.; Tanaka, K. Photochemical and radiolytic production of an organic hydride donor with a Ru-II complex containing an NAD(+) model ligand. Angew. Chem. Int. Ed. 2007, 46, 4169-4172.

10. Polyansky, D.E.; Cabelli, D.; Muckerman, J.T.; Fukushima, T.; Tanaka, K.; Fujita, E. Mechanism of hydride donor generation using a $\mathrm{Ru}(\mathrm{II})$ complex containing an $\mathrm{NAD}(+)$ model ligand: Pulse and steady-state radiolysis studies. Inorg. Chem. 2008, 47, 3958-3968.

11. Elvington, M.; Brewer, K.J. Photoinitiated electron collection at a metal in a rhodium-centered mixed-metal supramolecular complex. Inorg. Chem. 2006, 45, 5242-5244.

12. Arachchige, S.M.; Brown, J.; Brewer, K.J. Photochemical hydrogen production from water using the new photocatalyst $\left[\left\{(\text { bpy })_{2} \mathrm{Ru}(\mathrm{dpp})\right\}_{2} \mathrm{RhBr}_{2}\right]\left(\mathrm{PF}_{6}\right)_{5}$. J. Photochem. Photobiol. A Chem. 2008, 197, 13-17.

13. Arachchige, S.M.; Brown, J.R.; Chang, E.; Jain, A.; Zigler, D.F.; Rangan, K.; Brewer, K.J. Design considerations for a system for photocatalytic hydrogen production from water employing mixed-metal photochemical molecular devices for photoinitiated electron collection. Inorg. Chem. 2009, 48, 1989-2000.

14. Elvington, M.; Brown, J.; Arachchige, S.M.; Brewer, K.J. Photocatalytic hydrogen production from water employing a $\mathrm{Ru}, \mathrm{Rh}, \mathrm{Ru}$ molecular device for photoinitiated electron collection. J. Am. Chem. Soc. 2007, 129, 10644-10645.

15. White, T.A.; Higgins, S.L.H.; Arachchige, S.M.; Brewer, K.J. Efficient photocatalytic hydrogen production in a single-component system using $\mathrm{Ru}, \mathrm{Rh}, \mathrm{Ru}$ supramolecules containing 4,7-diphenyl-1,10-phenanthroline. Angew. Chem. Int. Ed. 2011, 50, 12209-12213.

16. White, T.A.; Rangan, K.; Brewer, K.J. Synthesis, characterization, and study of the photophysics and photocatalytic properties of the photoinitiated electron collector [ $\left.\left\{(\mathrm{phen})_{2} \mathrm{Ru}(\mathrm{dpp})\right\}_{2} \mathrm{RhBr}_{2}\right]$ (PF 6$)_{5}$. J. Photochem. Photobiol. A Chem. 2010, 209, 203-209.

17. Marcus, R.A. Electron transfer reactions in chemistry. Theory and experiment. Rev. Mod. Phys. 1993, 65, 599-610.

18. Marcus, R.A.; Sutin, N. Electron transfers in chemistry and biology. Biochim. Biophys. Acta 1985, 811, 265-322.

19. Nelson, J.; Kirkpatrick, J.; Ravirajan, P. Factors limiting the efficiency of molecular photovoltaic devices. Phys. Rev. B 2004, 69, 035337:1-035337:11.

20. Rosokha, S.V.; Kochi, J.K. Fresh look at electron-transfer mechanisms via the donor/acceptor bindings in the critical encounter complex. Acc. Chem. Res. 2008, 41, 641-653.

21. Navon, G.; Sutin, N. Mechanism of the quenching of the phosphorescence of tris(2,2'-bipyridine) ruthenium(II) by some cobalt(III) and ruthenium(III) complexes. Inorg. Chem. 1974, 13, 2159-2164.

22. Sutin, N.; Creutz, C. Electron-transfer reactions of excited states. J. Chem. Educ. 1983, 60, 809-814.

23. Bock, C.R.; Connor, J.A.; Gutierrez, A.R.; Meyer, T.J.; Whitten, D.G.; Sullivan, B.P.; Nagle, J.K. Estimation of excited-state redox potentials by electron-transfer quenching. Application of electron-transfer theory to excited-state redox processes. J. Am. Chem. Soc. 1979, 101, 4815-4824.

24. Creutz, C.; Sutin, N. Electron-transfer reactions of excited states: Direct evidence for reduction of the charge-transfer excited state of tris(2,2'-bipyridine)ruthenium(II). J. Am. Chem. Soc. 1976, 98, 6384-6385. 
25. Indelli, M.T.; Bignozzi, C.A.; Harriman, A.; Schoonover, J.R.; Scandola, F. Four intercomponent processes in a $\mathrm{Ru}(\mathrm{II})-\mathrm{Rh}(\mathrm{III})$ polypyridine dyad: Electron transfer from excited donor, electron transfer to excited acceptor, charge recombination, and electronic energy transfer. J. Am. Chem. Soc. 1994, 116, 3768-3779.

26. Indelli, M.T.; Chiorboli, C.; Flamigni, L.; de Cola, L.; Scandola, F. Photoinduced electron transfer across oligo-p-phenylene bridges. Distance and conformational effects in $\mathrm{Ru}(\mathrm{II}) / \mathrm{Rh}(\mathrm{III})$ dyads. Inorg. Chem. 2007, 46, 5630-5641.

27. Indelli, M.T.; Scandola, F.; Collin, J.-P.; Sauvage, J.-P.; Sour, A. Photoinduced electron and energy transfer in rigidly bridged $\mathrm{Ru}(\mathrm{II}) / \mathrm{Rh}(\mathrm{III})$ binuclear complexes. Inorg. Chem. 1996, 35, 303-312.

28. Indelli, M.T.; Scandola, F.; Flamigni, L.; Collin, J.P.; Sauvage, J.P.; Sour, A. Photoinduced electron transfer in ruthenium(II)/rhodium(III) terpyridine dyads. Inorg. Chem. 1997, 36, 4247-4250.

29. Furue, M.; Hirata, M.; Kinoshita, S.; Kushida, T.; Kamachi, M. Intramolecular electron-transfer of covalently-linked polypyridine ruthenium(II)/rhodium(III) binuclear complexes in the excited state. Observation of the marcus inverted region. Chem. Lett. 1990, 19, 2065-2068.

30. Kalyanasundaram, K.; Graetzel, M.; Nazeeruddin, M.K. Excited-state interactions in ligand-bridged chromophore-quencher complexes containing rhodium(III) and ruthenium(II) polypyridyl units. J. Phys. Chem. 1992, 96, 5865-5872.

31. Lee, J.-D.; Vrana, L.M.; Bullock, E.R.; Brewer, K.J. A tridentate-bridged ruthenium/rhodium complex as a stereochemically defined light-absorber/electron-acceptor Dyad. Inorg. Chem. 1998, 37, 3575-3580.

32. White, T.; Arachchige, S.; Sedai, B.; Brewer, K. Emission spectroscopy as a probe into photoinduced intramolecular electron transfer in polyazine bridged $\mathrm{Ru}(\mathrm{II}), \mathrm{Rh}(\mathrm{III})$ supramolecular complexes. Materials 2010, 3, 4328-4354.

33. Zigler, D.F.; Wang, J.; Brewer, K.J. Ruthenium(II)-polyazine light absorbers bridged to reactive cis-dichlororhodium(III) centers in a bimetallic molecular architecture. Inorg. Chem. 2008, 47, 11342-11350.

34. Kew, G.; DeArmond, K.; Hanck, K. Electrochemistry of rhodium-dipyridyl complexes. J. Phys. Chem. 1974, 78, 727-734.

35. Rasmussen, S.C.; Richter, M.M.; Yi, E.; Place, H.; Brewer, K.J. Synthesis and characterization of a series of novel rhodium and iridium complexes containing polypyridyl bridging ligands: Potential uses in the development of multimetal catalysts for carbon dioxide reduction. Inorg. Chem. 1990, 29, 3926-3932.

36. Anderson, C.P.; Salmon, D.J.; Meyer, T.J.; Young, R.C. Photochemical generation of Ru(bpy) ${ }_{3}{ }^{+}$ and $\mathrm{O}_{2}^{-}$. J. Am. Chem. Soc. 1977, 99, 1980-1982.

37. Haga, M.; Dodsworth, E.S.; Eryavec, G.; Seymour, P.; Lever, A.B.P. Luminescence quenching of the tris(2,2'-bipyrazine)ruthenium(II) cation and its monoprotonated complex. Inorg. Chem. 1985, 24, 1901-1906.

38. Lakowicz, J.R. Principles of Fluorescence Spectroscopy, 3rd ed.; Springer: Berlin, Heidelberg, Germany, 2006. 
39. Ballardini, R.; Varani, G.; Indelli, M.T.; Scandola, F.; Balzani, V. Free energy correlation of rate constants for electron transfer quenching of excited transition metal complexes. J. Am. Chem. Soc. 1978, 100, 7219-7223.

40. Brown, J.R.; Elvington, M.; Mongelli, M.T.; Zigler, D.F.; Brewer, K.J. Analytical methods development for supramolecular design in solar hydrogen production. Proc. SPIE 2006, 6340, doi:10.1117/12.680961.

(C) 2012 by the authors; licensee MDPI, Basel, Switzerland. This article is an open access article distributed under the terms and conditions of the Creative Commons Attribution license (http://creativecommons.org/licenses/by/3.0/). 